\title{
Methodology for Assessing Progeny Production and Grain Damage on Commodities Treated with Insecticides
}

\author{
Frank Arthur * and W. Robert Morrison III (D) \\ USDA-ARS-Center for Grain and Animal Health Research, 1515 College Avenue, Manhattan, KS 66502, USA; \\ william.morrison@usda.gov \\ * Correspondence: frank.arthur@usda.gov
}

Received: 21 April 2020; Accepted: 29 May 2020; Published: 5 June 2020

\begin{abstract}
In evaluating insecticides, progeny production on grain commodities can be evaluated by either exposing adults on a commodity for a given time period, then removing them and assessing mortality and progeny production, or by leaving the adults on the commodity continuously, and then assessing progeny production. Little research directly compares these methodologies. Thus, our aims were to: (1) determine residual efficacy of Diacon IGR+ (methoprene+deltamethrin) and Gravista (methoprene+deltamethrin+piperonyl butoxide) on wheat, corn, and brown rice over the course of a year, using bioassays with select stored product insects at different time intervals, and (2) directly compare the two different methods of parental adult exposure on progeny production. Adults were either exposed for $7 \mathrm{~d}$, then removed and assessed for survival, and the commodities were held for 6-7 weeks to assess progeny production, or adults were continuously exposed on the commodities for 6-7 weeks. Commodities were aged and sampled every 3 months for 12 months. Afterwards, samples were examined for progeny, sample weight loss, and insect feeding damage. Each insecticide killed exposed adults and prevented progeny of Rhyzopertha dominica on wheat and brown rice, and Tribolium castaneum on corn. There was extensive survival of Sitophilus spp. on all commodities, though Gravista did initially suppress S. oryzae on wheat and S. zeamais on corn compared to Diacon IGR+. Progeny, weight loss, and insect feeding damage were positively correlated in the $7 \mathrm{~d}$ exposure compared with continuous parental exposure. Both insecticides will control $R$. dominica and externally-feeding insects, but may exhibit reduced effectiveness for Sitophilus spp., especially $S$. oryzae. Food managers can utilize these data to more effectively plan management programs.
\end{abstract}

Keywords: storage; insects; control

\section{Introduction}

The insect growth regulator (IGR) methoprene has a long history of use as an insecticide in many agricultural systems throughout the world [1]. It has been evaluated and used alone and in combination with contact toxicants for many years to control stored product insects in Australia [2-4]. It was originally registered in the United States (US) as a grain protectant in the mid-1980s under the trade name Altosid ${ }^{\circledR}$, but that particular product was later withdrawn from the market [5]. Methoprene was reintroduced under the trade name Diacon II ${ }^{\circledR}$, at application rates of $1,2,5$, and 5 ppm for stored grains. This product was in turn replaced by Diacon IGR ${ }^{\circledR}$, at application rates of 1.25 and 2.5 ppm.

IGRs are only effective on immature insects and will not kill adults, a fact that must be acknowledged when conducting research with or promoting the use of IGRs. However, the methoprene-based IGR typically provides long-term protection against externally-feeding stored product insects in stored 
grains. In addition, it is also effective on Rhyzopertha dominica (Fab.), the lesser grain borer (Coleoptera: Bostrichidae) because the female lays an egg on the exterior of a grain kernel, which must hatch, and consequently, be exposed to the IGR prior to entering the kernel [5]. Thus, there is a brief time when the larva is exposed to the methoprene residues on the grain. The same study also showed that the IGR was effective on Sitotroga cerealella (Oliver), the Angoumois grain moth. Female conspecifics also lay eggs on the exterior of grain kernels, but recent studies show that it may be less susceptible to methoprene compared to R. dominica [5]. Sitophilus spp. weevils oviposit directly into a grain kernel, and thus, the developing larva will not normally be exposed to the residues; thus, IGRs are not considered to be effective on Sitophilus spp. weevils [5].

The pyrethroid deltamethrin (Centynal ${ }^{\circledR}$ ) can also be applied as a grain protectant in the US, at an application rate of $0.5 \mathrm{ppm}$. This contact toxicant will kill exposed stored product adults and larvae. A new product, Diacon IGR $+{ }^{\circledR}$, which combines methoprene with deltamethrin, as an adulticide, was introduced into the US market at application rates of $1.25 \mathrm{ppm}$ methoprene and $0.5 \mathrm{ppm}$ deltamethrin, or $2.5 \mathrm{ppm}$ methoprene $+1.0 \mathrm{ppm}$ deltamethrin. The contact toxicant was added to provide a measure of control against Sitophilus spp. [6]. More recently, an even newer formulation, which combines methoprene, deltamethrin, and the synergist piperonyl butoxide, tradename Gravista ${ }^{\circledR}$, has been registered by the US Environmental Protection Agency (USEPA) for direct application to stored grains. One of the hopes from the added synergist is to reduce the amount of active ingredient needed for each insecticide, while hopefully improving performance against resistant insects [7].

Many studies have documented variation in insecticidal efficacy depending on the crop substrate [8-15]. Some of these studies have involved the examination of IGRs in combination with contact toxicants. When evaluating the effects of IGRs, alone and in combination with contact insecticides, progeny production on grain commodities can be evaluated by exposing parental adults on a commodity for a given time period, then removing them to assess mortality and/or progeny production, or by leaving the adults continuously on the commodity, and then, assessing progeny production. There has been little research that directly compares these two methodologies in the same study. Thus, the objectives of this study were to: (1) Determine how the residual efficacy Diacon IGR+ and Gravista varies among wheat, corn, and brown rice, and (2) Compare the effects of the two methods of parental pesticide exposure on progeny production and physical grain damage.

\section{Materials and Methods}

\subsection{General Information}

These tests were conducted at the USDA-Agricultural Research Service (ARS) Center for Grain and Animal Health Research (CGAHR), Manhattan, KS, USA. The commodities used in this residual study were wheat, corn, and brown rice. The wheat was hard red winter wheat, obtained from a commercial farmer in Kansas, that had been stored at $-4{ }^{\circ} \mathrm{C}$ inside a large cold storage facility at the CGAHR for approximately $4-5$ years. The corn was obtained from a local grower and stored for about 4-5 years in the cold storage facility. The brown rice was obtained from a commercial milling facility in 2017 and had also been stored in the same facility as the wheat and the corn.

Different stored product insects were used depending on the crop, based on the most significant pests in each commodity after harvest. For wheat, the test insects were $R$. dominica, and Sitophilus oryzae (L.), the rice weevil (Coleoptera: Curculionidae). Both were cultured on the same variety of wheat described above, and the strain had been in culture for more than 30 years. They were held inside a growth chamber (Percival Scientific Inc., Perry, IA, USA), and set at $27^{\circ} \mathrm{C}$ and $60 \%$ RH. For assays with corn, Tribolium castaneum (Herbst) (Coleoptera: Tenebrionidae), the red flour beetle, and S. zeamais (Motschulsky) (Coleoptera: Curculionidae), the maize weevil, were used. The T. castaneum were cultured on a mixture of $95 \%$ whole wheat flour and $5 \%$ Brewer's yeast, while the S. zeamais were cultured on whole kernel corn, using the same variety as described above. Both species 
were also held in separate growth chambers at $27^{\circ} \mathrm{C}$ and $60 \% \mathrm{RH}$. For the tests with brown rice, the test species were $R$. dominica and T. castaneum.

\subsection{Insecticide Treatments and Bioassay Procedures for Wheat}

The insecticides used in this study were obtained from Central Life Sciences (Schaumberg, IL, USA). The first was the commercial formulation of Diacon IGR+, which contains $120 \mathrm{mg}$ active ingredient $[\mathrm{AI}] / \mathrm{mL}$ of the insect growth regulator (IGR) methoprene and $50 \mathrm{mg} \mathrm{AI} / \mathrm{mL}$ of the pyrethroid, deltamethrin. The label states a choice of two application rates, $1.25 \mathrm{ppm}$ methoprene $+0.5 \mathrm{ppm}$ deltamethrin, or $2.5 \mathrm{ppm}$ methoprene $+1.0 \mathrm{ppm}$ deltamethrin, hereafter referred to as the low (abbreviated: L Diacon IGR+) and high rates (H Diacon IGR + ), respectively. The second insecticide was Gravista, a mixture of methoprene + deltamethrin + the synergist piperonyl butoxide, at $27.5 \mathrm{mg}$ $\mathrm{AI} / \mathrm{mL}, 12 \mathrm{mg} \mathrm{AI} / \mathrm{mL}$, and $320 \mathrm{mg} \mathrm{AL} / \mathrm{mL}$, respectively, which was $1.125,0.5$, and $3.75 \mathrm{ppm}$, respectively. The above three insecticide treatments were compared to an untreated control that served as the fourth treatment.

The $5 \mathrm{~kg}$ of wheat was treated on 9 July 2018 with the low rate of Diacon IGR+, which according to the label rate is $283 \mathrm{~mL}$ of the formulation in $18.75 \mathrm{~L}$ of water to cover $27,273 \mathrm{~kg}$, which would give an equivalent rate of $0.052 \mathrm{~mL}$ of formulation in $0.35 \mathrm{~mL}$ water for $5 \mathrm{~kg}$. The amount of $0.052 \mathrm{~mL}$ was too small to formulate in $3.5 \mathrm{~mL}$, so a larger amount of $0.38 \mathrm{~mL}$ of Diacon IGR + was formulated in a $25 \mathrm{~mL}$ volumetric flask filled with distilled water to the level of $25 \mathrm{~mL}$, and applied at the rate of $0.35 \mathrm{~mL}$ of formulated solution per the $5 \mathrm{~kg}$ of wheat. Five separate replicates were treated in this manner by formulating each replicate in separate volumetric flasks so that the process of mixing the insecticide formulation with the distilled water could be done. Similarly, the high rate of Diacon IGR+ was double that of the low rate, so $0.76 \mathrm{~mL}$ was formulated in each of 5 separate $25 \mathrm{~mL}$ volumetric flasks with distilled water. Directions for the application of wheat for the Gravista product were obtained from Central Life Sciences, which corresponded to $1138 \mathrm{~mL}$ of the new formulation per $27,273 \mathrm{~kg}$, the equivalent of $0.20 \mathrm{~mL}$ in $3.5 \mathrm{~mL}$, or in $0.61 \mathrm{~mL} 10 \mathrm{~mL}$ distilled water. Each of the separate replicates for each treatment of Gravista were formulated in $10 \mathrm{~mL}$ of distilled water, and $3.5 \mathrm{~mL}$ was pipetted from the flask to treat the wheat.

During application for each replicate, the wheat was spread out on a $0.6 \times 0.3 \mathrm{~m}$ piece of a cardboard covered with plastic. The $3.5 \mathrm{~mL}$ of distilled water for the untreated wheat, or the $3.5 \mathrm{~mL}$ of formulated insecticide for the treated wheat, was dispensed into the filling cap of a Badger 100 artists' airbrush (Badger Corporation, Franklin Park, IL, USA), and equally misted over the wheat by applying about $0.8 \mathrm{~mL}$ of the formulation onto the wheat, mixing the wheat with a separate piece of cardboard, and dispensing another $0.8 \mathrm{~mL}$ and repeating the process. After each replicate was treated, it was transferred to an $18.75 \mathrm{~L}$ plastic bucket and covered with the lid. Separate artists' airbrushes were used for the untreated control and insecticide treatments. After the five replicates for each of the four treatments were completed, all buckets with commodities were transferred to the floor of an empty 112 MT grain bin at the CGAHR to mimic field conditions.

The day after the buckets were placed in the bin, the wheat was sampled and bioassayed as follows. About $80 \mathrm{~g}$ of wheat from each bucket was collected in four $120 \mathrm{~mL}$ plastic vials ( 80 vials total). A total of 10,1-week-old, mixed-sex adult $R$. dominica were exposed per replicate from each treatment for $7 \mathrm{~d}$, then removed with mortality assessed. This age range was used to allow for mating in the newly-emerged adults. In parallel, 10 adult $R$. dominica of the same age grouping, used for the reason stated above, were placed into a second set of vials with treated commodity, and allowed to remain to assess progeny production. Similarly, 10 1-2-week-old, mixed-sex adult $S$. oryzae were placed on $80 \mathrm{~g}$ per replicate, held for $7 \mathrm{~d}$, and then removed to assess for mortality, while the second set of vials for that species were held continuously for progeny production. All vials were then placed inside a walk-in chamber set at $27^{\circ} \mathrm{C}$ and $60 \% \mathrm{RH}$. After $7 \mathrm{~d}$, the appropriate vials containing R. dominica and S. oryzae were removed from the chamber, brought into the laboratory, the commodity was sifted, and the adults were recorded as live, knocked down (on their backs or unable to sustain motor movement), 
or dead (unresponsive when probed or prodded). The commodity was put back into the vials, and the vials returned to the incubator. After 7 more weeks, all vials were removed from the incubator and held for about a week in a freezer at about $-18{ }^{\circ} \mathrm{C}$. Subsequently, the vials were removed from the freezer, and allowed to warm on a laboratory counter. The wheat in each vial was first weighed on a Mettler balance. The wheat was then sifted to remove adult progeny, along with the frass and feeding damage. The wheat was weighed again, the frass was weighed, and number of adults was recorded. Progeny production for the group of $R$. dominica and S. oryzae that were continually exposed on the wheat was determined by subtracting the 10 original parental adults. After this process was completed, the wheat was discarded. This entire procedure was repeated by sampling the wheat, collecting the wheat for each replicated treatment in the vials, introducing the groups of $R$. dominica and S. oryzae held for 7 days or continuously exposed on the wheat. Samples were processed at 0,3, 6, 9, and 12 months after initial treatment of grain.

\subsection{Insecticide Treatment and Bioassay Procedures for Corn}

The corn was treated on 13 August 2018. The same treatments, untreated controls, the low and high rates of Diacon IGR+, and the one rate of Gravista were also used for corn with five replicates for each treatment. The label rate for treatment of the low rate of Diacon IGR+ on corn was $266 \mathrm{~mL}$ in $18.75 \mathrm{~L}$ for $25,454 \mathrm{~kg}$, which was equivalent to $0.052 \mathrm{~mL}$ for $5 \mathrm{~kg}$ of corn in a volumetric ratio of $3.7 \mathrm{~mL}$ in proportion to the label. Due to difficulties in measuring this small amount, $0.35 \mathrm{~mL}$ of formulation was mixed with water in a $25 \mathrm{~mL}$ flask, and for each replicate, $3.7 \mathrm{~mL}$ of the formulation was dispensed onto the corn using the airbrush system described for wheat. The amount of formulation was doubled for the high rate of Diacon IGR+. Thus, the amount of Gravista specified for treatment of corn was $1062 \mathrm{~mL}$ per $25,454 \mathrm{~kg}, 0.21 \mathrm{~mL}$ in $3.7 \mathrm{~mL}$ water, or 0.56 of the formulation in $10 \mathrm{~mL}$. The same volume of $3.7 \mathrm{~mL}$ described for the previous treatments was dispensed onto the corn. The treatment procedures were the same as described above for wheat regarding the dispensing of the insecticides (or untreated controls) onto the corn, placing each replicate in separate $18.75 \mathrm{~L}$ plastic buckets, and storing them on the floor of a different empty grain bin at the CGAHR.

The corn was first sampled after one day, as described for wheat. About $80 \mathrm{~g}$ of corn was collected into each of four 120-mL vials for each replicate and treatment (80 total). Ten mixed-sex adult 1-2-week-old T. castaneum or S. zeamais were placed in one vial for each of the four replicated treatments (20 total) and held for $7 \mathrm{~d}$ or put into the final set of vials for continuous exposure. The process of holding the corn in the chamber, and the subsequent analyses at 3, 6, 9, and 12 months, were the same as described for wheat.

\subsection{Insecticide Treatment and Bioassay Procedures for Brown Rice}

The brown rice was treated on 17 September 2018 with the same four treatments with five replicates as described above. Label specifications for treatment of brown rice with the low rate of Diacon IGR+ state application of $212 \mathrm{~mL}$ of formulation into $18.75 \mathrm{~mL}$ to cover $20,454 \mathrm{~kg}$, which is a volumetric spray rate of $4.6 \mathrm{~mL}$ per $5 \mathrm{~kg}$ of brown rice. The amount of $0.052 \mathrm{~mL}$ of Diacon IGR+ needed was again too small to be formulated into $4.6 \mathrm{~mL}$, so $0.28 \mathrm{~mL}$ was formulated into a $25 \mathrm{~mL}$ flask, and the airbrush system was used to dispense the $4.6 \mathrm{~mL}$ needed for each replicate and to treat the brown rice as described above. The amount of formulation was doubled for the high rate. The specifications for the Gravista were $845 \mathrm{~mL}$ of the formulation per $20,454 \mathrm{~kg}, 0.21 \mathrm{~mL} / 4.6 \mathrm{~mL}$, or $0.45 \mathrm{~mL}$ in $10 \mathrm{~mL}$, dispensed as $4.6 \mathrm{~mL}$ for each replicate. The five untreated control replicates were sprayed with $4.6 \mathrm{~mL}$ of distilled water. The process of treating the rice, transferring the rice to buckets and holding in the grain bin, and the subsequent sampling assessment procedures was as described for wheat and corn. The insect species were R. dominica and S. oryzae. 


\subsection{Statistical Analysis}

Data for the biological efficacy studies on each of the commodities were analyzed using Mixed-Model Procedures (e.g., proc mixed) in the Statistical Analysis System (SAS Version 9.4, SAS Institute, Cary, NC, USA). Data for wheat and brown rice were separated by species, with main effects for wheat and brown rice treatment and residual bioassay month, with analysis variables, progeny production in the 7 day exposures versus the continuous exposures, feeding damage, and frass weight. Interactions and random effects were also included in the Analysis of Variance (ANOVA). Data were also separated by species for the tests with corn and analyzed as described above for wheat and brown rice. The Means Procedure in SAS was used to generate mean values for comparisons, and these treatment means were separated using Tukey's Honest Significant Different Test, at $\alpha=0.05$, as an option under the Proc Mixed Procedure in SAS. When two treatments were compared, the $t$-test Procedure in SAS was used. Since post-treatment months were an ordered sequence, the data were not analyzed by mean separation tests, but instead were analyzed using month as a main effect, and separating data by month. A series of analyses using Proc Corr in SAS was also done for each commodity to correlate the initial parental mortality of each insect species with progeny production, correlate progeny production, sample weight loss, and frass weight of samples when parental adults were exposed for 7 days with the samples when adults were continuously exposed, and combining all samples and correlating progeny production with sample weight loss and progeny production, and also correlating frass weight with sample weight loss. Data were combined for all treatments for these correlation analyses.

\section{Results}

\subsection{Wheat}

The ANOVA analyses for R. dominica and S. oryzae after the 7 day exposures are shown in Table 1. Main effects for month, treatment, and their interactions, were generally significant for the percentage of live adults, adults that were knocked down, or adults that were dead for $R$. dominica, except for the main effect of month for live adults. All main effects and interactions were significant for S. oryzae. The percentage of live $R$. dominica in untreated controls after the 7 day exposure ranged from $92 \%$ to $100 \%$ depending on month, with few knocked down or dead (Table 2). There were only a few live adults in any of the treatments at bioassay months $0-9$, and mortality was generally over $90 \%$. At month 12 , there was an increase in percentage knockdown with a corresponding decrease in mortality in all of the treatments. There were no instances where there were significant differences in live adults, adults knocked down, and dead adults between the three insecticide treatments. At month 0 (one day after treatment), the percentage of live S. oryzae in the Gravista treatment was less than in controls or the two rates of Diacon IGR+, but after that time, there were live adults in all treatments, and in some instances, the percentage of live adults was greater in the Gravista treatment than in the highest rate of Diacon IGR+ (Table 2). At months 9 and 12, most of the adults exposed on the treated wheat were alive or knocked down, with few dead adults in any of the treatments.

There were no $F_{1}$ progeny for $R$. dominica when parental adults were either exposed continuously on the treated wheat or removed after the 7 day exposures, so two-way $t$-tests were done by month to determine differences in the two exposure regimes on number of $F_{1}$ progeny, percentage of sample weight loss caused by adults and/or progeny, and feeding damage in untreated controls (Table 3). Progeny production ranged from 47.6 to 33.8 individual adults, depending on month and exposure, and was greater in samples where adults were continually exposed compared with removal after 7 days. Percentage weight loss ranged from $1.65 \%$ to $6.27 \%$ and was greater in samples where parental adults were continuously exposed in three of the five possible comparisons. Feeding damage ranged from $0.80 \mathrm{~g}$ to $4.51 \mathrm{~g}$ and was greater in samples where parental adults were continuously exposed in four of five comparisons. 
Table 1. ANOVA Table for main effects month (MO), treatment (TR, untreated controls, the low and high rates of Diacon IGR+, and the Gravista formulation) for the percentage (means \pm SE) of adult $R$. dominica and S. oryae that were alive (Live), knocked down (KD), or dead (D) after 7 days of exposure on treated wheat.

\begin{tabular}{cllrrr}
\hline Species & Response & Variable & \multicolumn{1}{c}{$\boldsymbol{F}$} & \multicolumn{1}{c}{ df } & \multicolumn{1}{c}{$\boldsymbol{p}$} \\
\hline R. dominica & Live & MO & 1.9 & 4,79 & 0.114 \\
& & TRT & 3160.3 & 3,79 & $<0.001$ \\
& & MO*TRT & 1.1 & 12,79 & 0.392 \\
\cline { 2 - 6 } & KD & MO & 11.6 & 4,79 & $<0.001$ \\
& & TRT & 2.5 & 3,79 & 0.064 \\
& MO*TRT & 2.3 & 12,79 & 0.014 \\
\cline { 2 - 6 } & Dead & MO & 12.1 & 4,79 & $<0.001$ \\
& & TRT & 605.9 & 3,79 & $<0.001$ \\
& MO*TRT & 1.9 & 12,79 & 0.046 \\
\hline S. oryzae & MO & 20.7 & 4,79 & $<0.001$ \\
& & TRT & 58.5 & 3,79 & $<0.001$ \\
& & MO*TRT & 17.0 & 12,79 & $<0.001$ \\
\cline { 2 - 6 } & KD & MO & 57.3 & 4,159 & $<0.001$ \\
& & TRT & 15.3 & 3,159 & $<0.001$ \\
& & MO*TRT & 14.3 & 12,159 & $<0.001$ \\
\cline { 2 - 6 } & Dead & MO & 32.1 & 4,159 & $<0.001$ \\
& & TRT & 42.2 & 3,159 & $<0.001$ \\
& & MO*TRT & 17.8 & 12,159 & $<0.001$ \\
\hline
\end{tabular}

Table 2. Percentage (means \pm SE) of $R$. dominica and S. oryzae alive (Live), knocked down (KD), or dead (means \pm SE) seven days after exposure on untreated wheat (UTC) or wheat treated with the low rate of Diacon IGR+ (LDiacon IGR+, 0.5 ppm deltamethrin + 1.25 ppm methoprene), the high rate of Diacon IGR+ (HDiacon IGR+, $1.0 \mathrm{ppm}+2.5 \mathrm{ppm}$ methoprene), or the new Gravista formulation (methoprene + deltamethrin + piperonyl butoxide synergist). Data are separated by month, bioassays were done at 0 months (1 day), and 3, 6, 9, and 12 months after treatment ${ }^{1}$.

\begin{tabular}{lllrrr}
\hline Month & Treatment & Species & \multicolumn{1}{c}{ \% Live } & \% KD & \multicolumn{1}{c}{ \% Dead } \\
\hline 0 & UTC & R. dominica & $100.0 \pm 0.0 \mathrm{a}$ & $0.0 \pm 0.0 \mathrm{a}$ & $0.0 \pm 0.0 \mathrm{~b}$ \\
& LDiacon IGR+ & & $0.0 \pm 0.0 \mathrm{~b}$ & $0.0 \pm 0.0 \mathrm{a}$ & $100.0 \pm 0.0 \mathrm{a}$ \\
& HDiacon IGR+ & & $0.0 \pm 0.0 \mathrm{~b}$ & $0.0 \pm 0.0 \mathrm{a}$ & $100.0 \pm 0.0 \mathrm{a}$ \\
& Gravista & & $0.0 \pm 0.0 \mathrm{~b}$ & $0.0 \pm 0.0 \mathrm{a}$ & $100.0 \pm 0.0 \mathrm{a}$ \\
\cline { 2 - 6 } & UTC & S. oryzae & $100.0 \pm 0.0 \mathrm{a}$ & $0.0 \pm 0.0 \mathrm{a}$ & $0.0 \pm 0.0 \mathrm{~b}$ \\
& LDiacon IGR+ & & $95.0 \pm 5.0 \mathrm{a}$ & $0.0 \pm 0.0 \mathrm{a}$ & $5.0 \pm 5.0 \mathrm{~b}$ \\
HDiacon IGR+ & & $100.0 \pm 5.0 \mathrm{a}$ & $0.0 \pm 0.0 \mathrm{a}$ & $0.0 \pm 0.0 \mathrm{~b}$ \\
Gravista & & $4.0 \pm 4.0 \mathrm{~b}$ & $5.0 \pm 5.0 \mathrm{a}$ & $91.0 \pm 5.7 \mathrm{a}$ \\
\hline \multirow{3}{*}{3} & R. dominica & $96.2 \pm 2.3 \mathrm{a}$ & $0.0 \pm 0.0 \mathrm{a}$ & $3.8 \pm 2.3 \mathrm{~b}$ \\
& UTC & $0.0 \pm 0.0 \mathrm{~b}$ & $0.0 \pm 0.0 \mathrm{a}$ & $100.0 \pm 0.0 \mathrm{a}$ \\
& LDiacon IGR+ & & $0.0 \pm 0.0 \mathrm{~b}$ & $0.0 \pm 0.0 \mathrm{a}$ & $100.0 \pm 0.0 \mathrm{a}$ \\
HDiacon IGR+ & & $0.0 \pm 0.0 \mathrm{~b}$ & $3.8 \pm 2.3 \mathrm{a}$ & $96.2 \pm 2.3 \mathrm{a}$ \\
\hline Gravista & & $100.0 \pm 0.0 \mathrm{a}$ & $0.0 \pm 0.0 \mathrm{a}$ & $0.0 \pm 0.0 \mathrm{c}$ \\
& UTC & S. oryzae & $64.6 \pm 8.1 \mathrm{~b}$ & $1.8 \pm 1.8 \mathrm{a}$ & $33.6 \pm 6.5 \mathrm{~b}$ \\
& LDiacon IGR+ & & $42.0 \pm 9.1 \mathrm{c}$ & $2.0 \pm 2.0 \mathrm{a}$ & $56.0 \pm 10.3 \mathrm{a}$ \\
& HDiacon IGR+ & & $48.0 \pm 13.6 \mathrm{bc}$ & $4.0 \pm 4.0 \mathrm{a}$ & $48.0 \pm 12.8 \mathrm{ab}$ \\
\hline Gravista & & & &
\end{tabular}


Table 2. Cont

\begin{tabular}{|c|c|c|c|c|c|}
\hline Month & Treatment & Species & $\%$ Live & $\% \mathrm{KD}$ & $\%$ Dead \\
\hline \multirow[t]{8}{*}{6} & UTC & R. dominica & $95.8 \pm 2.6 \mathrm{a}$ & $0.0 \pm 0.0 \mathrm{a}$ & $4.2 \pm 2.6 \mathrm{~b}$ \\
\hline & LDiacon IGR+ & & $2.0 \pm 2.0 \mathrm{~b}$ & $0.0 \pm 0.0 \mathrm{a}$ & $98.0 \pm 2.0 \mathrm{a}$ \\
\hline & HDiacon IGR+ & & $0.0 \pm 0.0 \mathrm{~b}$ & $0.0 \pm 0.0 \mathrm{a}$ & $100.0 \pm 0.0 \mathrm{a}$ \\
\hline & Gravista & & $0.0 \pm 0.0 \mathrm{~b}$ & $3.8 \pm 2.3 \mathrm{a}$ & $96.2 \pm 2.3 \mathrm{a}$ \\
\hline & UTC & S. oryzae & $100.0 \pm 0.0 \mathrm{a}$ & $0.0 \pm 0.0 \mathrm{a}$ & $0.0 \pm 0.0 \mathrm{~b}$ \\
\hline & LDiacon IGR+ & & $98.2 \pm 1.8 \mathrm{a}$ & $0.0 \pm 0.0 \mathrm{a}$ & $1.8 \pm 1.8 b$ \\
\hline & HDiacon IGR+ & & $37.0 \pm 4.3 \mathrm{~b}$ & $0.0 \pm 0.0 \mathrm{a}$ & $68.0 \pm 8.6 a$ \\
\hline & Gravista & & $51.0 \pm 16.1 \mathrm{~b}$ & $0.0 \pm 0.0 \mathrm{a}$ & $48.9 \pm 16.6 \mathrm{a}$ \\
\hline \multirow[t]{8}{*}{9} & UTC & R. dominica & $92.0 \pm 5.8 \mathrm{a}$ & $8.0 \pm 5.8 \mathrm{a}$ & $0.0 \pm 0.0 \mathrm{~b}$ \\
\hline & LDiacon IGR+ & & $1.8 \pm 1.8 \mathrm{~b}$ & $0.0 \pm 0.0 \mathrm{a}$ & $98.2 \pm 2.3 \mathrm{a}$ \\
\hline & HDiacon IGR+ & & $0.0 \pm 0.0 \mathrm{~b}$ & $3.9 \pm 2.4 \mathrm{a}$ & $96.2 \pm 2.3 \mathrm{a}$ \\
\hline & Gravista & & $0.0 \pm 0.0 \mathrm{~b}$ & $5.8 \pm 3.9 \mathrm{a}$ & $94.2 \pm 3.9 \mathrm{a}$ \\
\hline & UTC & S. oryzae & $100.0 \pm 0.0 \mathrm{a}$ & $0.0 \pm 0.0 \mathrm{c}$ & $0.0 \pm 0.0 \mathrm{a}$ \\
\hline & LDiacon IGR+ & & $79.6 \pm 4.8 b$ & $18.6 \pm 3.4 b$ & $1.8 \pm 1.8 \mathrm{a}$ \\
\hline & HDiacon IGR+ & & $40.7 \pm 6.3 c$ & $59.3 \pm 6.4 \mathrm{a}$ & $0.0 \pm 0.0$ \\
\hline & Gravista & & $75.7 \pm 8.6 b$ & $24.2 \pm 8.6 b$ & $0.0 \pm 0.0 \mathrm{a}$ \\
\hline \multirow[t]{8}{*}{12} & UTC & LGB & $100.0 \pm 0.0 \mathrm{a}$ & $0.0 \pm 0.0 \mathrm{~b}$ & $0.0 \pm 0.0 \mathrm{~b}$ \\
\hline & LDiacon IGR+ & & $2.0 \pm 2.0 \mathrm{~b}$ & $14.2 \pm 3.9 b$ & $83.8 \pm 3.9 \mathrm{a}$ \\
\hline & HDiacon IGR+ & & $0.0 \pm 0.0 \mathrm{~b}$ & $16.0 \pm 5.1 \mathrm{a}$ & $84.0 \pm 5.1 \mathrm{a}$ \\
\hline & Gravista & & $5.7 \pm 3.9 b$ & $29.3 \pm 12.8 \mathrm{a}$ & $65.0 \pm 16.3 a$ \\
\hline & UTC & S. oryzae & $100.0 \pm 0.0 \mathrm{a}$ & $0.0 \pm 0.0 \mathrm{a}$ & $0.0 \pm 0.0 \mathrm{a}$ \\
\hline & LDiacon IGR+ & & $100.0 \pm 0.0 \mathrm{a}$ & $0.0 \pm 0.0 \mathrm{a}$ & $0.0 \pm 0.0 \mathrm{a}$ \\
\hline & HDiacon IGR+ & & $100.0 \pm 0.0 \mathrm{a}$ & $0.0 \pm 0.0 \mathrm{a}$ & $0.0 \pm 0.0 \mathrm{a}$ \\
\hline & Gravista & & $100.0 \pm 0.0 \mathrm{a}$ & $0.0 \pm 0.0 \mathrm{a}$ & $0.0 \pm 0.0 \mathrm{a}$ \\
\hline
\end{tabular}

${ }^{1}$ Means within columns followed by the same lowercase letter are not significantly different ( $\left.p \geq 0.05\right)$ Proc Mixed, SAS, Tukey's Honest Significant Difference Test). Data separated by species due to the obvious difference in susceptibility between the two species.

A complete ANOVA analysis was done for S. oryzae, with main effects for month, treatment, and exposure regime, and all their interactions, for variables $F_{1}$ progeny, sample weight loss, and feeding damage (Table 4). All main effects were significant for all three variables, while interactions were significant only for month by treatment and month by exposure for $\mathrm{F}_{1}$ progeny, and only month by treatment for weight loss and feeding damage. A series of analyses was then done by separating the two exposure regimes and analyzing for differences between treatments (including controls) for $\mathrm{F}_{1}$ progeny, sample weight loss, and feeding damage (Table 5). At months $0-6$, there were more progeny in untreated controls and the low rate of Diacon IGR+ compared to the high rate and Gravista treatments, but there were few differences at 9 and 12 months. After month 0 , average progeny ranged from a low of 22.8 in the high rate of Diacon IGR+ to a high of 401.7 in the low rate, with month to month variation. At 12 months, progeny were so numerous in untreated controls that the samples could not be processed due to excessive fungal development, along with the high progeny numbers. Values for sample weight loss and feeding damage followed the same general pattern as shown for $F_{1}$ progeny development, with little difference between untreated controls and treatments at month 9 , but with slightly less weight loss and feeding damage at month 12 in the Gravista treatment for the 7 day parental exposures. Overall, the $\mathrm{F}_{1}$ progeny numbers were generally comparable to or greater than $F_{1}$ progeny of $R$. dominica, but the sample weight loss and feeding damage caused by $S$. oryzae was less than that caused by $R$. dominica. In contrast to $R$. dominica, frass weight never exceeded one gram in the $S$. oryzae samples for any treatment including controls. 
Table 3. Number of $F_{1}$ adult progeny, \% of sample weight loss due to insect feeding, and feeding damage (frass) (mean \pm SE for all) from exposure of ten mixed-sex parental adult $R$. dominica exposed continuously for about 8 weeks (Cont.) on $\sim 80 \mathrm{~g}$ of untreated wheat (UTC), or parental adults were removed after 1 week and samples were held for an additional 8 weeks ( 7 day). Data are separated by month. No progeny development on wheat treated with low and high rates of Diacon IGR+ or the Gravista formulation; no overall ANOVA done, only comparison between the two parental exposure regimes. Data are separated by month, bioassays were done at 1 day (month 0 ), and 3, 6, 9 , and 12 months after treatment ${ }^{1}$.

\begin{tabular}{cccccc}
\hline Month & Treatment & Exposure & Progeny & \%Wt. Loss & Frass (g) \\
\hline 0 & UTC & Cont. & $47.6 \pm 8.8 \mathrm{a}$ & $2.51 \pm 0.41$ & $1.16 \pm 0.32 \mathrm{a}$ \\
& & 7 day & $68.2 \pm 21.0 \mathrm{a}$ & $1.65 \pm 0.36$ & $0.80 \pm 0.21 \mathrm{a}$ \\
\hline 3 & UTC & Cont. & $235.4 \pm 33.0 \mathrm{a}$ & $6.27 \pm 0.58 \mathrm{a}$ & $2.96 \pm 0.40 \mathrm{a}$ \\
& & 7 day & $165.2 \pm 29.9 \mathrm{~b}$ & $3.83 \pm 0.63 \mathrm{~b}$ & $1.76 \pm 0.35 \mathrm{~b}$ \\
\hline \multirow{2}{*}{6} & UTC & Cont. & $333.8 \pm 48.1 \mathrm{a}$ & $5.74 \pm 0.58 \mathrm{a}$ & $3.42 \pm 0.21 \mathrm{a}$ \\
& & 7 day & $173.2 \pm 42.5 \mathrm{~b}$ & $4.60 \pm 0.99 \mathrm{a}$ & $1.78 \pm 0.35 \mathrm{~b}$ \\
\hline \multirow{2}{*}{9} & UTC & Cont. & $108.4 \pm 9.5 \mathrm{a}$ & $4.61 \pm 0.22 \mathrm{a}$ & $2.78 \pm 0.18 \mathrm{a}$ \\
& & 7 day & $89.4 \pm 13.0 \mathrm{a}$ & $2.46 \pm 0.47 \mathrm{~b}$ & $1.42 \pm 0.26 \mathrm{~b}$ \\
\hline \multirow{2}{*}{12} & UTC & Cont. & $134.0 \pm 5.7 \mathrm{a}$ & $6.39 \pm 0.39 \mathrm{a}$ & $4.51 \pm 0.39 \mathrm{a}$ \\
& & 7 day & $158.8 \pm 9.4 \mathrm{a}$ & $3.54 \pm 0.21 \mathrm{~b}$ & $2.56 \pm 0.13 \mathrm{~b}$ \\
\hline
\end{tabular}

${ }_{1}$ Means for exposure for progeny, weight loss, and frass weight, followed by the same lowercase letter, are not significantly different ( $p \geq 0.05$, Proc $t$-test, SAS).

Table 4. ANOVA Table for main effects month (MO), Treatment (untreated controls, two rates of Diacon IGR+, and the Gravista formulation product), and count (CT, parental insects removed after 7 days or left continuously on the wheat for 8 weeks), and all associated interactions, for S. oryzae $\mathrm{F}_{1}$ progeny, $\%$ of sample weight loss, and weight in grams of feeding damage.

\begin{tabular}{|c|c|c|c|c|}
\hline Response & Variable & $F$ & df & $p$ \\
\hline \multirow[t]{7}{*}{$\mathrm{F}_{1}$ Progeny } & $\mathrm{MO}$ & 8.4 & 4,159 & $<0.001$ \\
\hline & TRT & 30.1 & 3,159 & $<0.001$ \\
\hline & $\mathrm{CT}$ & 56.2 & 1,159 & $<0.001$ \\
\hline & $\mathrm{MO}^{*} \mathrm{TRT}$ & 4.1 & 12,159 & $<0.001$ \\
\hline & $\mathrm{MO}^{*} \mathrm{CT}$ & 5.7 & 4,159 & $<0.001$ \\
\hline & $\mathrm{TRT}^{*} \mathrm{CT}$ & 2.2 & 3,159 & 0.092 \\
\hline & $\mathrm{MO}^{*} \mathrm{TRT}^{*} \mathrm{CT}$ & 2.4 & 12,159 & 0.009 \\
\hline \multirow[t]{7}{*}{ \% Weight Loss } & MO & 7.2 & 4,159 & $<0.001$ \\
\hline & TRT & 30.4 & 3,159 & $<0.001$ \\
\hline & $\mathrm{CT}$ & 17.7 & 1,159 & $<0.001$ \\
\hline & MO*TRT & 1.8 & 12,159 & 0.060 \\
\hline & $\mathrm{MO}^{*} \mathrm{CT}$ & 0.7 & 4,159 & 0.616 \\
\hline & $\mathrm{TRT}^{*} \mathrm{CT}$ & 0.9 & 3,159 & 0.454 \\
\hline & $\mathrm{MO}^{*} \mathrm{TRT}^{*} \mathrm{CT}$ & 0.8 & 12,159 & 0.629 \\
\hline \multirow[t]{7}{*}{ Frass Weight (g) } & $\mathrm{MO}$ & 11.4 & 4,159 & $<0.001$ \\
\hline & TRT & 32.4 & 3,159 & $<0.001$ \\
\hline & $\mathrm{CT}$ & 7.6 & 1,159 & 0.007 \\
\hline & MO*TRT & 2.0 & 12,159 & 0.032 \\
\hline & $\mathrm{MO}^{*} \mathrm{CT}$ & 1.4 & 4,159 & 0.221 \\
\hline & $\mathrm{TRT}^{*} \mathrm{CT}$ & 0.3 & 3,159 & 0.796 \\
\hline & $\mathrm{MO}^{*} \mathrm{TRT}^{*} \mathrm{CT}$ & 0.8 & 12,159 & 0.666 \\
\hline
\end{tabular}


Table 5. Number of $F_{1}$ adult progeny, \% of sample weight loss due to insect feeding, and feeding damage (frass) (mean \pm SE for all) from exposure of ten mixed-sex parental adult $S$. oryzae exposed on $\sim 80$ g of untreated wheat (UTC) wheat or wheat treated with the low rate of Diacon IGR+ (LDiacon IGR+, 0.5 ppm deltamethrin + 1.25 ppm methoprene), the high rate of Diacon IGR+ (HDiacon IGR+, $1.0 \mathrm{ppm}+2.5 \mathrm{ppm}$ methoprene), or the Gravista. Parental adults were either continuously exposed for about 8 weeks (Cont.) or were removed after 1 week and samples were held for an additional 8 weeks (7 day). Data are separated by month, bioassays were done at 1 day (month 0), and 3, 6, 9, and 12 months after treatment ${ }^{1,2}$.

\begin{tabular}{|c|c|c|c|c|c|}
\hline Month & Treatment & Exposure & Progeny & $\% W t$. Loss & Frass (g) \\
\hline \multirow[t]{8}{*}{0} & UTC & Cont. & $191.0 \pm 16.2 \mathrm{a}$ & $2.28 \pm 0.43 a$ & $0.38 \pm 0.09 a$ \\
\hline & LDiacon IGR+ & & $138.0 \pm 39.7 \mathrm{a}$ & $1.66 \pm 0.48 \mathrm{ab}$ & $0.16 \pm 0.07 \mathrm{~b}$ \\
\hline & HDiacon IGR+ & & $61.4 \pm 36.9 b$ & $0.74 \pm 0.37 \mathrm{~b}$ & $0.08 \pm 0.06 b$ \\
\hline & Gravista & & $43.0 \pm 17.1 \mathrm{~b}$ & $0.37 \pm 0.18 b$ & $0.04 \pm 0.02 b$ \\
\hline & UTC & 7 day & $114.8 \pm 15.5 \mathrm{a}$ & $1.52 \pm 0.22 \mathrm{a}$ & $0.29 \pm 0.13 a$ \\
\hline & LDiacon IGR+ & & $160.8 \pm 34.3 \mathrm{a}$ & $1.43 \pm 0.34 \mathrm{a}$ & $0.36 \pm 0.11 \mathrm{a}$ \\
\hline & HDiacon IGR+ & & $53.8 \pm 19.1 b$ & $0.43 \pm 0.14 b$ & $0.06 \pm 0.04 b$ \\
\hline & Gravista & & $12.6 \pm 7.7 \mathrm{bc}$ & $0.17 \pm 0.18 b$ & $0.00 \pm 0.00 \mathrm{~b}$ \\
\hline \multirow[t]{8}{*}{3} & UTC & Cont. & $296.4 \pm 56.8 \mathrm{a}$ & $3.08 \pm 0.55 \mathrm{a}$ & $0.60 \pm 0.15 a$ \\
\hline & LDiacon IGR+ & & $270.8 \pm 39.9 a$ & $2.60 \pm 0.43 a b$ & $0.56 \pm 0.07 a$ \\
\hline & HDiacon IGR+ & & $81.6 \pm 24.8 b$ & $1.32 \pm 0.36 \mathrm{~b}$ & $0.18 \pm 0.09 b$ \\
\hline & Gravista & & $97.2 \pm 59.8 b$ & $1.30 \pm 0.52 b$ & $0.18 \pm 0.16 b$ \\
\hline & UTC & 7 day & $175.8 \pm 35.1 \mathrm{a}$ & $3.00 \pm 0.68 \mathrm{ab}$ & $0.56 \pm 0.13 a$ \\
\hline & LDiacon IGR+ & & $107.6 \pm 21.1 \mathrm{a}$ & $1.80 \pm 0.39 b$ & $0.44 \pm 0.13 a$ \\
\hline & HDiacon IGR+ & & $42.0 \pm 20.3 b$ & $0.92 \pm 0.27 b$ & $0.16 \pm 0.09 b$ \\
\hline & Gravista & & $51.4 \pm 28.3 b$ & $1.05 \pm 0.30 \mathrm{ab}$ & $0.14 \pm 0.12 b$ \\
\hline \multirow[t]{8}{*}{6} & UTC & Cont. & $128.8 \pm 41.7 \mathrm{~b}$ & $1.65 \pm 0.45 b$ & $0.54 \pm 0.20 a$ \\
\hline & LDiacon IGR+ & & $401.7 \pm 90.7 \mathrm{a}$ & $3.11 \pm 0.58 \mathrm{a}$ & $0.90 \pm 0.15 a$ \\
\hline & HDiacon IGR+ & & $124.0 \pm 28.7 \mathrm{~b}$ & $1.13 \pm 0.26 \mathrm{~b}$ & $0.38 \pm 0.10 a$ \\
\hline & Gravista & & $262.8 \pm 75.9 \mathrm{ab}$ & $1.77 \pm 0.59 \mathrm{~b}$ & $0.48 \pm 0.14 a$ \\
\hline & UTC & 7 day & $125.4 \pm 14.1 \mathrm{a}$ & $1.74 \pm 0.28 \mathrm{a}$ & $0.56 \pm 0.07 a$ \\
\hline & LDiacon IGR+ & & $131.2 \pm 12.5 \mathrm{a}$ & $1.61 \pm 0.29 a$ & $0.72 \pm 0.10 \mathrm{a}$ \\
\hline & HDiacon IGR+ & & $22.8 \pm 6.3 \mathrm{~b}$ & $0.38 \pm 0.18 b$ & $0.10 \pm 0.04 b$ \\
\hline & Gravista & & $61.0 \pm 15.3 \mathrm{ab}$ & $0.56 \pm 0.16 b$ & $0.14 \pm 0.05 b$ \\
\hline \multirow[t]{8}{*}{9} & UTC & Cont. & $146.6 \pm 23.5 \mathrm{a}$ & $1.94 \pm 0.36 \mathrm{a}$ & $0.60 \pm 0.13 a$ \\
\hline & LDiacon IGR+ & & $145.8 \pm 26.1 \mathrm{a}$ & $2.04 \pm 0.49 a$ & $0.46 \pm 0.10 \mathrm{a}$ \\
\hline & HDiacon IGR+ & & $55.8 \pm 14.1 \mathrm{~b}$ & $0.60 \pm 0.10 b$ & $0.16 \pm 0.04 b$ \\
\hline & Gravista & & $49.6 \pm 13.5 b$ & $0.76 \pm 0.14 b$ & $0.24 \pm 0.08 \mathrm{~b}$ \\
\hline & UTC & 7 day & $97.0 \pm 21.1 \mathrm{a}$ & $1.52 \pm 0.58 \mathrm{a}$ & $0.46 \pm 0.05 a$ \\
\hline & LDiacon IGR+ & & $79.6 \pm 9.7 \mathrm{ab}$ & $0.87 \pm 0.07 \mathrm{a}$ & $0.28 \pm 0.06 \mathrm{ab}$ \\
\hline & HDiacon IGR+ & & $32.8 \pm 7.6 \mathrm{~b}$ & $0.59 \pm 0.16 a$ & $0.06 \pm 0.02 b$ \\
\hline & Gravista & & $58.5 \pm 13.4 \mathrm{ab}$ & $0.67 \pm 0.16 \mathrm{a}$ & $0.15 \pm 0.06 b$ \\
\hline \multirow[t]{8}{*}{12} & $\mathrm{UTC}^{2}$ & Cont. & . & & r \\
\hline & LDiacon IGR+ & & $129.8 \pm 6.5 \mathrm{a}$ & $1.39 \pm 0.16 \mathrm{a}$ & $0.40 \pm 0.03 a$ \\
\hline & HDiacon IGR+ & & $88.6 \pm 17.3 \mathrm{a}$ & $1.32 \pm 0.39 a$ & $0.24 \pm 0.06 \mathrm{~b}$ \\
\hline & Gravista & & $103.8 \pm 17.4 \mathrm{a}$ & $1.12 \pm 0.21 \mathrm{a}$ & $0.38 \pm 0.05 a b$ \\
\hline & $\mathrm{UTC}^{2}$ & 7 day & . & . & . \\
\hline & LDiacon IGR+ & & $88.8 \pm 18.1 \mathrm{a}$ & $1.17 \pm 0.16 \mathrm{a}$ & $0.34 \pm 0.02 \mathrm{a}$ \\
\hline & HDiacon IGR+ & & $61.6 \pm 9.7 \mathrm{a}$ & $0.75 \pm 0.09 a b$ & $0.30 \pm 0.03 \mathrm{ab}$ \\
\hline & Gravista & & $61.1 \pm 8.1 \mathrm{a}$ & $0.65 \pm 0.13 b$ & $0.22 \pm 0.04 b$ \\
\hline
\end{tabular}

\footnotetext{
1 Means for treatment within columns for both parental exposure conditions, for all three variables, followed by the same lowercase letters are not significantly different $(p \geq 0.05) .{ }^{2}$ There were so many S. oryzae progeny in untreated controls at 12 months that the samples were moldy and could not be processed.
} 
Survival of parental $R$. dominica was strongly correlated with progeny production, but there was considerable variation in F1 progeny even when survival was 100\% (Figure 1A). Survival of parental S. oryzae was also correlated with progeny production but there was more variation at levels where parental survival was less than $100 \%$ compared to $R$. dominica, and also variation when survival was $100 \%$ (Figure 1B). Progeny production of both species in the 7 day exposures was correlated with production in the continuous exposures, but with more variation, and hence, a lower $r$ value in S. oryzae (Figure 2A,B). Similarly, sample weight loss and frass weight was correlated for R. dominica and S. oryzae (Figure 2C-F), with stronger correlation and greater $r$ values for $R$. dominica compared to $S$. oryzae. For the final set of correlations, progeny production of both species was strongly correlated with sample weight loss (Figure 3A,B) and frass weight (Figure 3C,D), and frass weight was correlated with sample weight loss (Figure 3D,E). The $r$ values for all correlations in Figure 3 ranged from 0.721 to 0.831 .
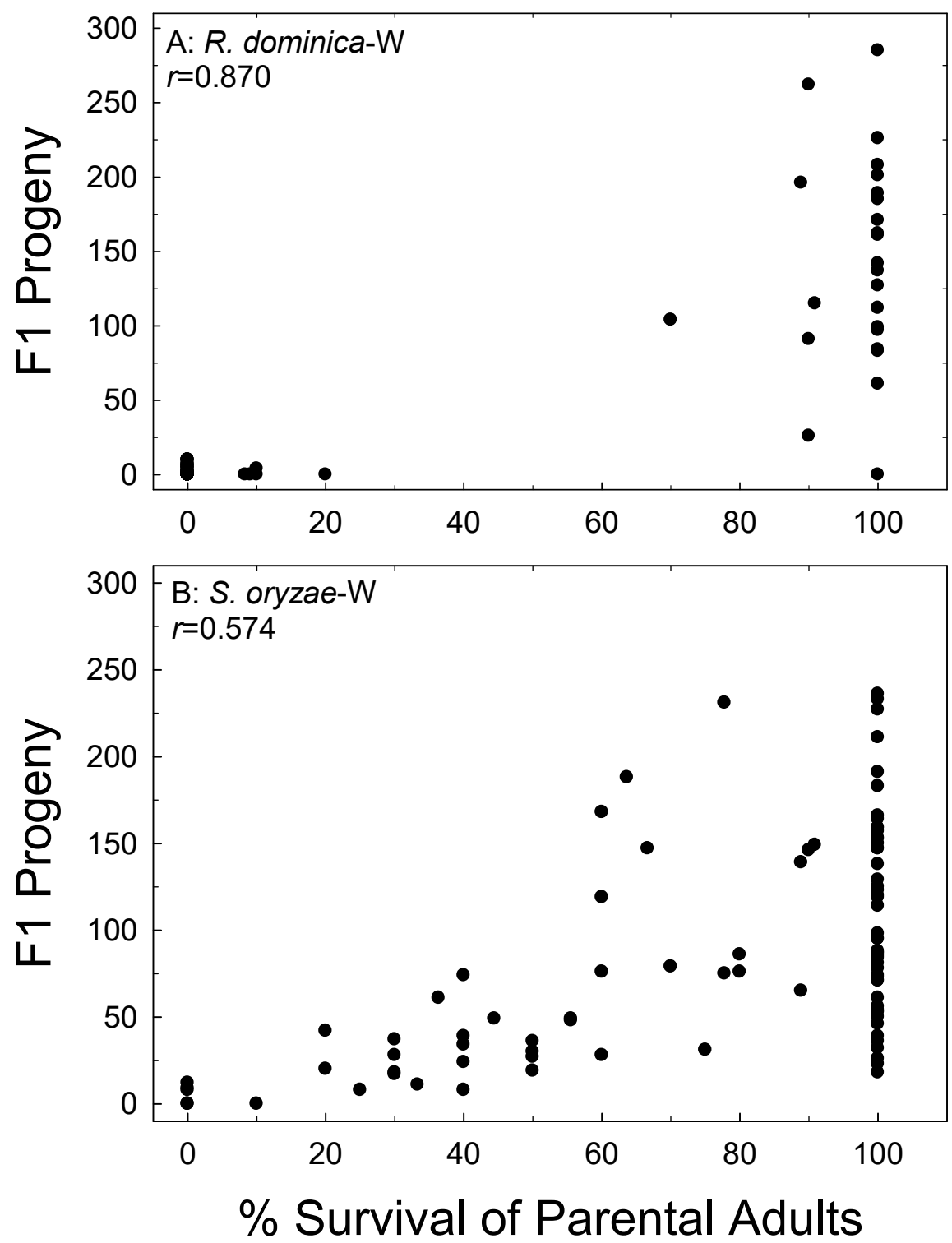

Figure 1. Correlation of parental survival with $\mathrm{F}_{1}$ progeny production of $R$. dominica (A) and S. oryzae (B) on wheat $(\mathrm{W})$. Data combined for all treatments and all bioassay months. 

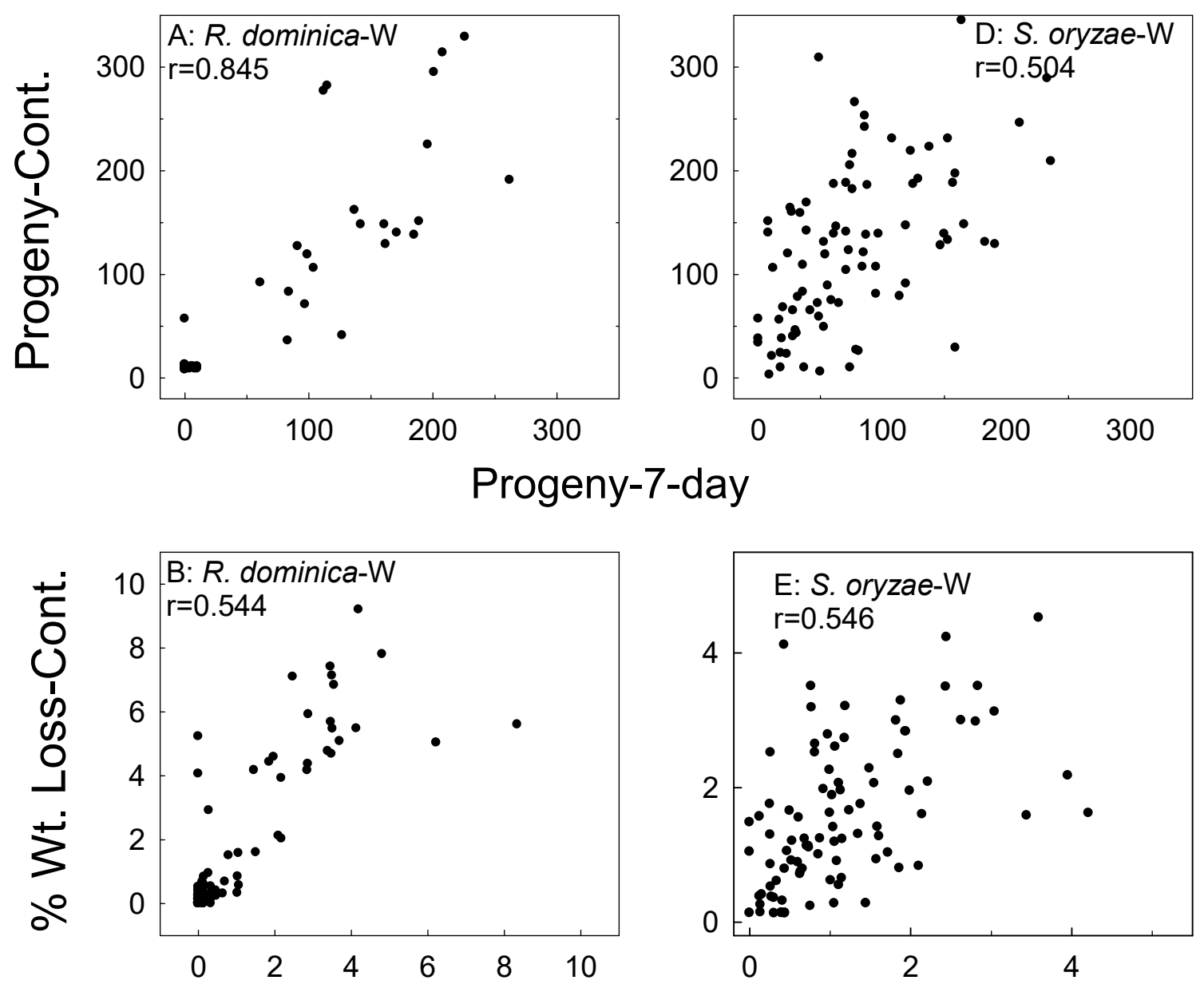

\%Wt. Loss-7-day Exp.

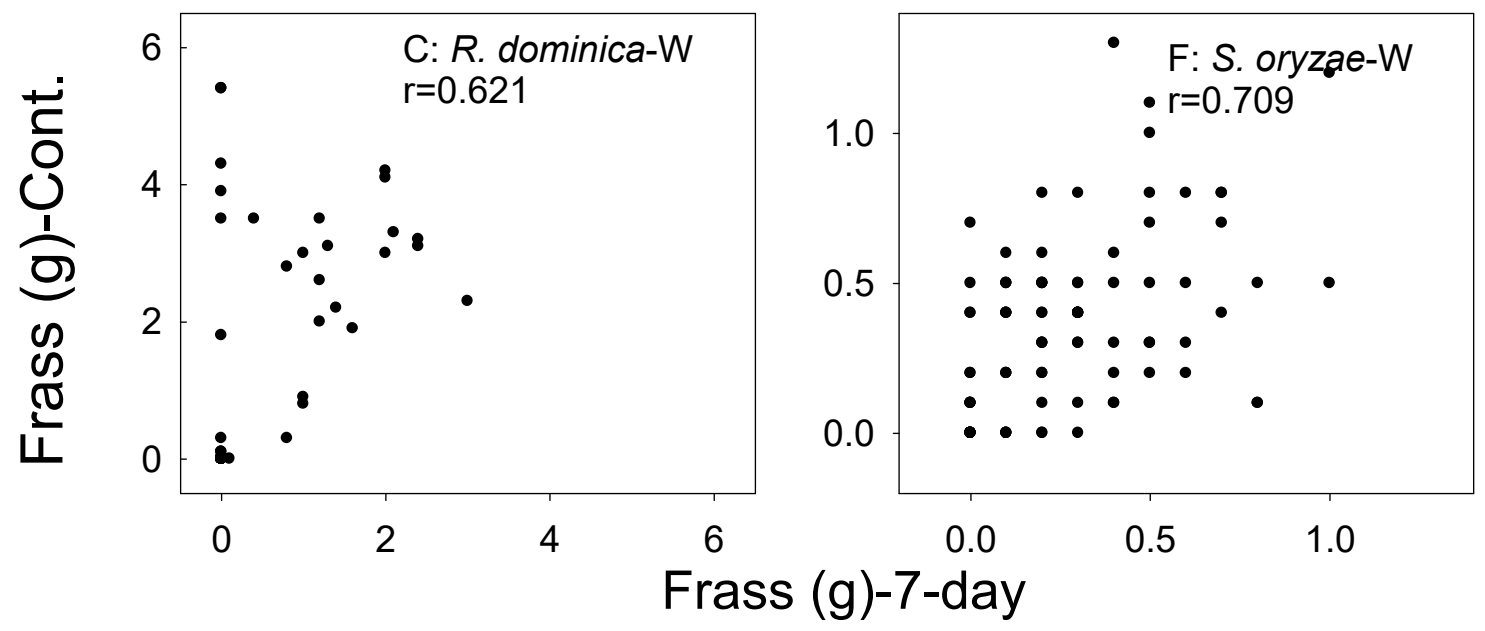

Figure 2. Correlation of $F_{1}$ progeny, sample weight loss, and feeding damage (frass weight) in the wheat $(\mathrm{W})$ samples whereby parental adults were exposed for 7 days versus the continual exposures of parental adults for R. dominica (A-C) and S. oryzae (D-F). Data combined for all treatments and all bioassay months. 

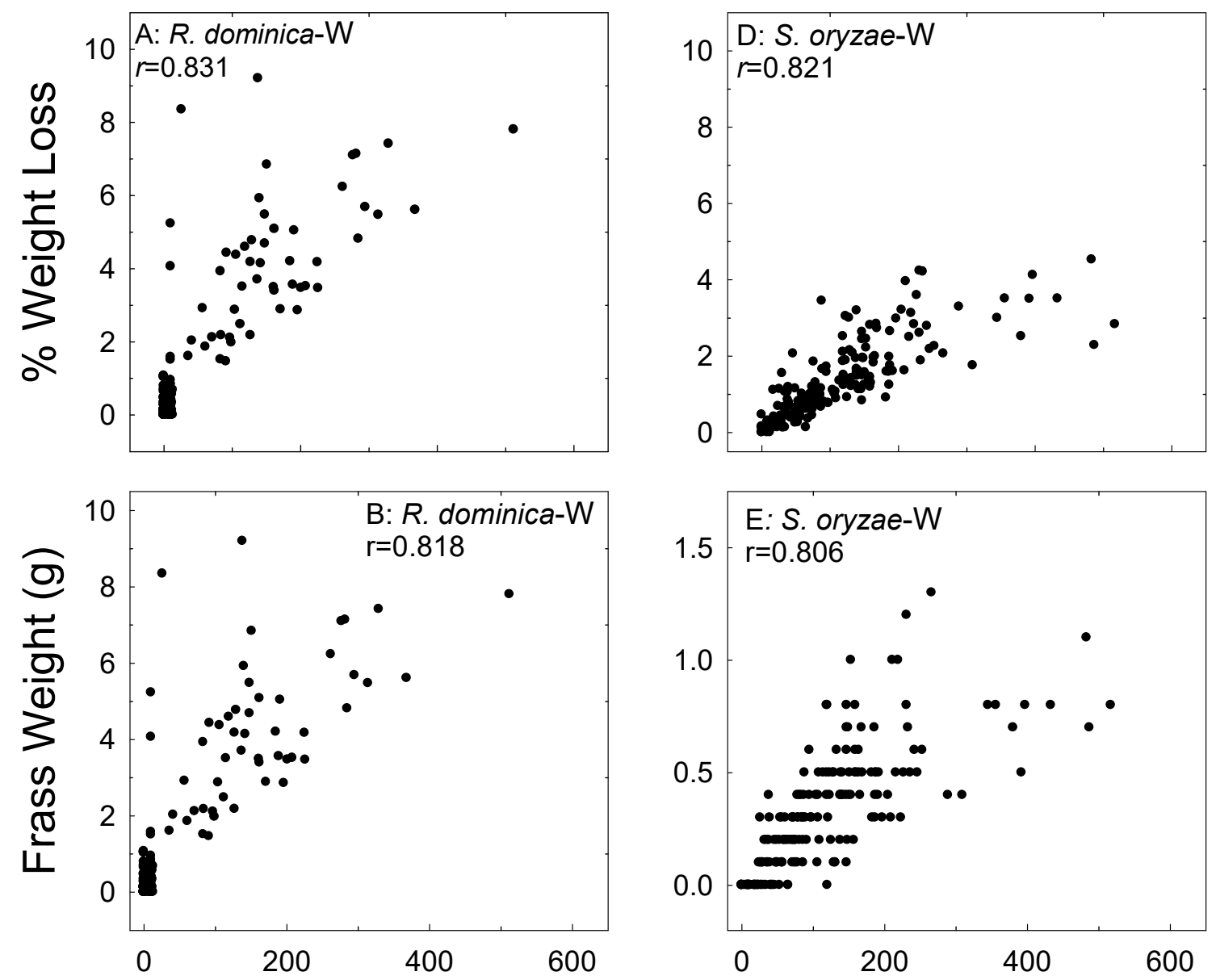

F1 Progeny
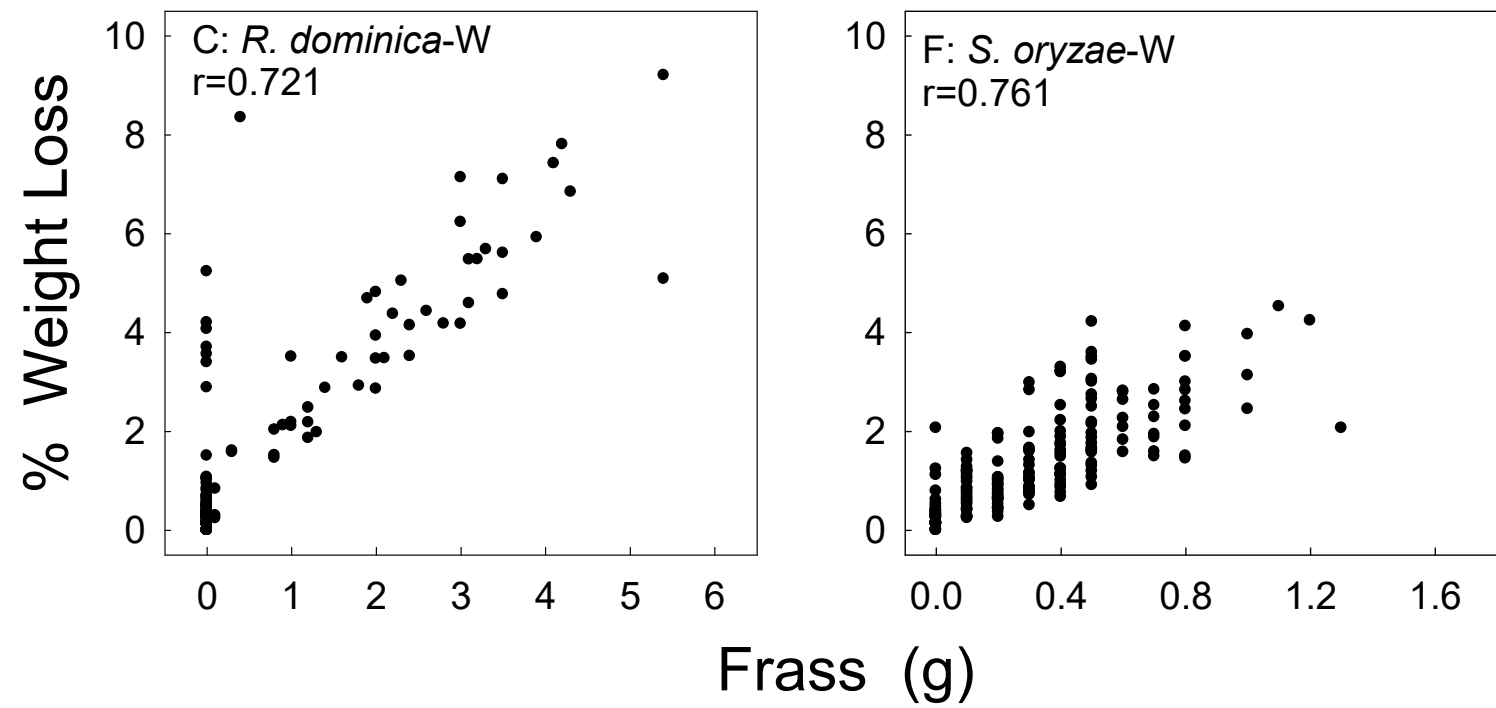

Figure 3. Correlation of wheat $(\mathrm{W})$ sample weight loss and frass weight with $\mathrm{F}_{1}$ progeny of $R$. dominica $(\mathbf{A}, \mathbf{B})$, sample weight loss with frass weight $(\mathbf{C})$, sample weight loss and frass weight with $\mathrm{F}_{1}$ progeny of $S$. oryzae $(\mathbf{D}, \mathbf{E})$, and sample weight loss and frass weight $(\mathbf{F})$. Data for the two parental exposure regimes combined, data for all treatments and all bioassay months combined. 


\subsection{Corn}

The ANOVA for the 7 day exposures of T. castaneum and S. oryzae is shown in Table 6. Except for the main effect for month and variable live adults of $T$. castaneum, all main effects and interactions were significant for percentage live, knocked down, or dead adults after exposure. A series of one-way ANOVAs was done next by month for the three variables (Table 7). All exposed T. castaneum adults on untreated controls were alive after 7 days at all bioassay months except for month 12 . The percentage of live, knocked down, and dead adults in the treatments varied considerably with month; for example, the average of dead adults on the low rate of Diacon IGR+ was $92 \%$ at month 6, and $0 \%$ and $56.9 \%$ at months 3 and 12, respectively. The percentage of live adults in the Gravista treatment was always 0 but rarely lower than the percentages of live adults in the two Diacon IGR+ treatments. All S. zeamais in the untreated corn were alive after the 7 day exposures (Table 7). The percentage of live adults was lower in the Gravista treatment compared to the two Diacon IGR+ treatments at months 0, 3, and 12 , but there were no differences between treatments at month 6 . Knockdown in the two Diacon IGR+ treatments ranged from 0 to 69.1 at months 0 and 3 but at 6 and 12 months did not exceed $18.2 \%$. Similarly, the percentages of dead S. zeamais seemed to fluctuate with month in all three insecticide treatments but was generally greatest in the Gravista treatment.

Table 6. ANOVA Table for main effects month (MO), treatment (TR, untreated controls, two rates of Diacon IGR+, and the Gravista formulation for the percentage of adult T. castaneum and S. zeamais that were alive (Live), knocked down (KD), or dead (D) after 7 days of exposure on corn.

\begin{tabular}{cllrrr}
\hline Species & Response & Variable & \multicolumn{1}{c}{$\boldsymbol{F}$} & \multicolumn{1}{c}{ df } & \multicolumn{1}{c}{$\boldsymbol{P}$} \\
\hline T. castaneum & Live & MO & 2.6 & 3,61 & 0.059 \\
& & TRT & 438.2 & 3,61 & $<0.001$ \\
& & MO*TRT & 3.5 & 12,61 & 0.002 \\
\cline { 2 - 6 } & KD & MO & 60.6 & 3,61 & $<0.001$ \\
& & TRT & 77.5 & 3,61 & $<0.001$ \\
& MOad & MO & 53.8 & 3,61 & $<0.001$ \\
& & TRT & 42.7 & 3,61 & $<0.001$ \\
& & MO*TRT & 11.3 & 9,61 & $<0.001$ \\
\hline S. zeamais & Live & MO & 23.2 & 3,60 & $<0.001$ \\
& & TRT & 47.9 & 3,60 & $<0.001$ \\
& & MO*TRT & 7.0 & 9,60 & $<0.001$ \\
\cline { 2 - 6 } & KD & MO & 10.6 & 3,60 & $<0.001$ \\
& & TRT & 7.8 & 3,60 & $<0.001$ \\
& & MO*TRT & 6.0 & 9,60 & $<0.001$ \\
\cline { 2 - 6 } & Dead & MO & 30.1 & 3,60 & $<0.001$ \\
& & TRT & 32.2 & 3,60 & $<0.001$ \\
& & MO*TRT & 9.6 & 9,60 & $<0.001$ \\
\hline
\end{tabular}


Table 7. Percentage (means \pm SE) of T. castaneum and S. zeamais alive (Live), knocked down (KD), or dead (means \pm SE) seven days after exposure on untreated corn (UTC) or on corn treated with the low rate of Diacon IGR+ (LDiacon IGR+, 0.5 ppm deltamethrin +1.25 ppm methoprene), the high rate of Diacon IGR+ (HDiacon IGR+, $1.0 \mathrm{ppm}+2.5 \mathrm{ppm}$ ), or the Gravista (methoprene + deltamethrin + piperonyl butoxide synergist). Data are separated by month, bioassays were done at 0 months (1 day), and $3,6,9$, and 12 months after treatment ${ }^{1,2}$.

\begin{tabular}{|c|c|c|c|c|c|}
\hline Month & Treatment & Species & \% Live & $\% \mathrm{KD}$ & $\%$ Dead \\
\hline \multirow[t]{8}{*}{0} & UTC & T. castaneum & $100.0 \pm 0.0 \mathrm{a}$ & $0.0 \pm 0.0 \mathrm{~b}$ & $0.0 \pm 0.0 \mathrm{~b}$ \\
\hline & LDiacon IGR+ & & $17.7 \pm 6.1 b$ & $68.1 \pm 6.4 \mathrm{a}$ & $14.2 \pm 9.2 \mathrm{ab}$ \\
\hline & HDiacon IGR+ & & $0.0 \pm 0.0 \mathrm{~b}$ & $74.9 \pm 5.9 \mathrm{a}$ & $25.1 \pm 5.9 \mathrm{a}$ \\
\hline & Gravista & & $0.0 \pm 0.0 \mathrm{~b}$ & $76.0 \pm 6.0 \mathrm{a}$ & $24.0 \pm 6.0 \mathrm{a}$ \\
\hline & UTC & S. zeamais & $100.0 \pm 0.0 \mathrm{a}$ & $0.0 \pm 0.0 \mathrm{~b}$ & $0.0 \pm 0.0 c$ \\
\hline & LDiacon IGR+ & & $53.5 \pm 7.7 \mathrm{~b}$ & $29.0 \pm 7.0 \mathrm{a}$ & $17.5 \pm 7.7 \mathrm{bc}$ \\
\hline & HDiacon IGR+ & & $29.4 \pm 7.1 \mathrm{~b}$ & $29.6 \pm 9.6 \mathrm{a}$ & $40.9 \pm 14.3 b$ \\
\hline & Gravista & & $0.0 \pm 0.0 \mathrm{c}$ & $0.0 \pm 0.0 \mathrm{~b}$ & $100.0 \pm 0.0 \mathrm{a}$ \\
\hline \multirow[t]{8}{*}{3} & UTC & T. castaneum & $100.0 \pm 0.0 \mathrm{a}$ & $0.0 \pm 0.0 \mathrm{c}$ & $0.0 \pm 0.0 \mathrm{~b}$ \\
\hline & LDiacon IGR+ & & $4.4 \pm 4.4 \mathrm{~b}$ & $83.5 \pm 9.3 \mathrm{a}$ & $12.0 \pm 9.7 \mathrm{~b}$ \\
\hline & HDiacon IGR+ & & $0.0 \pm 0.0 \mathrm{~b}$ & $22.9 \pm 5.7 \mathrm{bc}$ & $77.1 \pm 5.7 \mathrm{a}$ \\
\hline & Gravista & & $0.0 \pm 0.0 \mathrm{~b}$ & $14.2 \pm 11.6 \mathrm{bc}$ & $85.8 \pm 11.6 \mathrm{a}$ \\
\hline & UTC & S. zeamais & $100.0 \pm 0.0 \mathrm{a}$ & $0.0 \pm 0.0 \mathrm{c}$ & $0.0 \pm 0.0 \mathrm{~b}$ \\
\hline & LDiacon IGR+ & & $60.4 \pm 6.8 b$ & $39.6 \pm 6.8 b$ & $0.0 \pm 0.0 \mathrm{~b}$ \\
\hline & HDiacon IGR+ & & $77.8 \pm 12.3 b$ & $20.0 \pm 13.0 \mathrm{~b}$ & $2.2 \pm 2.2 \mathrm{~b}$ \\
\hline & Gravista & & $2.0 \pm 2.0 \mathrm{c}$ & $69.1 \pm 9.2 \mathrm{a}$ & $28.0 \pm 8.9 \mathrm{a}$ \\
\hline \multirow[t]{8}{*}{6} & UTC & T. castaneum & $100.0 \pm 0.0 \mathrm{a}$ & $0.0 \pm 0.0 \mathrm{~b}$ & $0.0 \pm 0.0 \mathrm{~b}$ \\
\hline & LDiacon IGR+ & & $8.0 \pm 3.7 \mathrm{~b}$ & $0.0 \pm 0.0 \mathrm{~b}$ & $92.0 \pm 3.7 \mathrm{a}$ \\
\hline & HDiacon IGR+ & & $0.0 \pm 0.0 \mathrm{c}$ & $98.0 \pm 2.0 \mathrm{a}$ & $2.0 \pm 2.0 \mathrm{~b}$ \\
\hline & Gravista & & $0.0 \pm 0.0 c$ & $98.0 \pm 2.0 \mathrm{a}$ & $2.0 \pm 2.0 \mathrm{~b}$ \\
\hline & UTC & S. zeamais & $100.0 \pm 0.0 \mathrm{a}$ & $0.0 \pm 0.0 \mathrm{~b}$ & $0.0 \pm 0.0 \mathrm{~b}$ \\
\hline & LDiacon IGR+ & & $100.0 \pm 0.0 \mathrm{a}$ & $0.0 \pm 0.0 \mathrm{~b}$ & $0.0 \pm 0.0 \mathrm{~b}$ \\
\hline & HDiacon IGR+ & & $70.0 \pm 13.0 \mathrm{a}$ & $10.0 \pm 7.7 \mathrm{a}$ & $2.0 \pm 2.0 \mathrm{~b}$ \\
\hline & Gravista & & $88.0 \pm 7.3 \mathrm{a}$ & $0.0 \pm 0.0 \mathrm{~b}$ & $48.9 \pm 16.6 \mathrm{a}$ \\
\hline \multirow[t]{8}{*}{12} & UTC & T. castaneum & $87.9 \pm 4.6 \mathrm{a}$ & $2.3 \pm 2.3 \mathrm{a}$ & $9.8 \pm 4.1 \mathrm{c}$ \\
\hline & LDiacon IGR+ & & $23.2 \pm 11.4 b$ & $19.9 \pm 10.5 \mathrm{a}$ & $56.9 \pm 12.0 \mathrm{~b}$ \\
\hline & HDiacon IGR+ & & $25.0 \pm 10.4 \mathrm{~b}$ & $25.0 \pm 13.2 \mathrm{a}$ & $50.1 \pm 4.1 \mathrm{~b}$ \\
\hline & Gravista & & $0.0 \pm 0.0 \mathrm{~b}$ & $10.0 \pm 5.4 \mathrm{a}$ & $90.0 \pm 5.4 \mathrm{a}$ \\
\hline & UTC & S. zeamais & $100.0 \pm 0.0 \mathrm{a}$ & $0.0 \pm 0.0 \mathrm{a}$ & $0.0 \pm 0.0 \mathrm{~b}$ \\
\hline & LDiacon IGR+ & & $82.4 \pm 4.9 \mathrm{a}$ & $0.0 \pm 0.0 \mathrm{a}$ & $17.6 \pm 4.9 \mathrm{~b}$ \\
\hline & HDiacon IGR+ & & $62.5 \pm 15.5 \mathrm{a}$ & $0.0 \pm 0.0 \mathrm{a}$ & $37.5 \pm 15.5 \mathrm{a}$ \\
\hline & Gravista & & $48.0 \pm 13.2 \mathrm{~b}$ & $18.2 \pm 12.0 \mathrm{a}$ & $34.0 \pm 7.0 \mathrm{a}$ \\
\hline
\end{tabular}

${ }_{1}$ Means within columns followed by the same lowercase letter are not significantly different $(p \geq 0.05$, Proc Mixed, SAS, Tukey's Honest Significant Difference Test). Data separated by species. ${ }^{2}$ No data for mortality after the 7 day exposures for month 9 .

The ANOVA for main effects of month, treatment, and exposure condition for variables $\mathrm{F}_{1}$ progeny, sample weight loss, and weight of feeding damage were all significant at $P<0.001$, except with weight loss by month due to T. castaneum (Table 8). Only about half of the interactions were significant for both species. The series of one-way ANOVAs was then done by month and exposure conditions for both species. Tribolium castaneum did not complete develop on corn treated with any of the three insecticides, and sample weight loss and feeding damage was negligible, thus data are reported only for untreated controls; however, progeny production to the adult stage was low even on the untreated controls, except for month 12, likely because whole grains are not a preferred food source for T. castaneum (Table 9). The only significant difference for progeny production occurred at month 3 , when progeny production was unexpectedly greater when the parental adults were removed after $7 \mathrm{~d}$ compared to the continuous exposure of parental adults. Weight loss and feeding damage was 
greatest for the continual exposures of parental adults at months 6-12, and all months except month 9 , respectively. Average progeny production of $S$. zeamais in the three insecticide treatments ranged from 0 to 67.2, fluctuated with month, and was generally lower than progeny in untreated controls; however, progeny production was rarely different among the three insecticide treatments in either the continuous parental exposures or samples whereby the parental adults were removed after 7 days (Table 10). Similarly, the percentage weight loss and amount of feeding damage in the insecticide treatments was usually less than in the controls, but rarely different from each other except for scattered samples during the 12 month testing period.

Table 8. ANOVA Table for main effects month (MO), treatment (untreated controls, two rates of Diacon IGR+, and the Gravista formulation), and count (CT, parental insects removed after 7 days or left continuously on the corn for 8 weeks), and all associated interactions, for T. castaneum and S. zeamais $\mathrm{F}_{1}$ progeny, \% of sample weight loss, and weight in grams of feeding damage.

\begin{tabular}{|c|c|c|c|c|c|}
\hline Species & Response & Variable & $F$ & df & $p$ \\
\hline \multirow[t]{21}{*}{ T. castaneum } & \multirow[t]{7}{*}{$\mathrm{F}_{1}$ Progeny } & $\mathrm{MO}$ & 23.9 & 4,159 & $<0.001$ \\
\hline & & TRT & 192.3 & 3,159 & $<0.001$ \\
\hline & & CT & 323.2 & 1,159 & $<0.001$ \\
\hline & & MO*TRT & 21.4 & 12,159 & $<0.001$ \\
\hline & & $\mathrm{MO}{ }^{*} \mathrm{CT}$ & 3.2 & 4, 159 & 0.013 \\
\hline & & $\mathrm{TRT}^{*} \mathrm{CT}$ & 0.6 & 3,159 & 0.652 \\
\hline & & $\mathrm{MO}^{*} \mathrm{TRT}^{*} \mathrm{CT}$ & 1.9 & 12,159 & 0.043 \\
\hline & \multirow{7}{*}{$\%$ Weight Loss } & $\mathrm{MO}$ & 1.6 & 4,159 & 0.162 \\
\hline & & TRT & 23.8 & 3,159 & $<0.001$ \\
\hline & & CT & 8.3 & 1,159 & 0.005 \\
\hline & & MO*TRT & 2.1 & 12,159 & 0.020 \\
\hline & & $\mathrm{MO}^{*} \mathrm{CT}$ & 0.6 & 4,159 & 0.654 \\
\hline & & $\mathrm{TRT}^{*} \mathrm{CT}$ & 2.5 & 3,159 & 0.059 \\
\hline & & $\mathrm{MO}^{*} \mathrm{TRT}^{*} \mathrm{CT}$ & 1.9 & 12,159 & 0.038 \\
\hline & \multirow[t]{7}{*}{ Frass Weight } & $\mathrm{MO}$ & 15.3 & 4,159 & $<0.001$ \\
\hline & & TRT & 270.8 & 3,159 & $<0.001$ \\
\hline & & $\mathrm{CT}$ & 20.5 & 1,159 & $<0.001$ \\
\hline & & $\mathrm{MO}^{*} \mathrm{TRT}$ & 15.4 & 12,159 & $<0.001$ \\
\hline & & $\mathrm{MO}^{*} \mathrm{CT}$ & 2.9 & 4,159 & 0.023 \\
\hline & & $\mathrm{TRT}^{*} \mathrm{CT}$ & 20.8 & 3,159 & $<0.001$ \\
\hline & & $\mathrm{MO}^{*} \mathrm{TRT}^{*} \mathrm{CT}$ & 1.9 & 12,159 & 0.033 \\
\hline \multirow[t]{21}{*}{ S. zeamais } & \multirow[t]{7}{*}{$\mathrm{F}_{1}$ Progeny } & $\mathrm{MO}$ & 37.1 & 4,155 & $<0.001$ \\
\hline & & TRT & 26.3 & 3,155 & $<0.001$ \\
\hline & & $\mathrm{CT}$ & 37.7 & 1,155 & $<0.001$ \\
\hline & & MO*TRT & 2.6 & 12,155 & 0.004 \\
\hline & & $\mathrm{MO}^{*} \mathrm{CT}$ & 4.4 & 4,155 & 0.002 \\
\hline & & $\mathrm{TRT}^{*} \mathrm{CT}$ & 0.4 & 3,155 & 0.724 \\
\hline & & $\mathrm{MO}^{*} \mathrm{TRT}^{*} \mathrm{CT}$ & 1.8 & 12,155 & 0.053 \\
\hline & \multirow[t]{7}{*}{ \% Weight Loss } & $\mathrm{MO}$ & 23.6 & 4,155 & $<0.001$ \\
\hline & & TRT & 30.7 & 3,155 & $<0.001$ \\
\hline & & $\mathrm{CT}$ & 25.2 & 1,155 & $<0.001$ \\
\hline & & $\mathrm{MO}^{*} \mathrm{TRT}$ & 2.1 & 12,155 & 0.024 \\
\hline & & $\mathrm{MO}^{*} \mathrm{CT}$ & 2.0 & 4,155 & 0.102 \\
\hline & & $\mathrm{TRT}^{*} \mathrm{CT}$ & 1.9 & 3,155 & 0.132 \\
\hline & & $\mathrm{MO}^{*} \mathrm{TRT}^{*} \mathrm{CT}$ & 2.7 & 12,155 & 0.002 \\
\hline & \multirow[t]{7}{*}{ Frass Weight } & $\mathrm{MO}$ & 36.9 & 4,159 & $<0.001$ \\
\hline & & TRT & 33.0 & 3,159 & $<0.001$ \\
\hline & & $\mathrm{CT}$ & 41.0 & 1,159 & $<0.001$ \\
\hline & & MO*TRT & 1.7 & 12,159 & 0.075 \\
\hline & & $\mathrm{MO}^{*} \mathrm{CT}$ & 6.3 & 4,159 & $<0.001$ \\
\hline & & $\mathrm{TRT}^{*} \mathrm{CT}$ & 1.8 & 3,159 & 0.158 \\
\hline & & $\mathrm{MO}^{*} \mathrm{TRT}^{*} \mathrm{CT}$ & 2.1 & 12,159 & 0.022 \\
\hline
\end{tabular}


Table 9. Number of $F_{1}$ adult progeny, \% of sample weight loss due to insect feeding, and feeding damage (frass) (mean \pm SE for all) from exposure of ten mixed-sex parental adult $T$. castaneum exposed continuously for about 8 weeks (Cont.) on $\sim 80 \mathrm{~g}$ of untreated corn (UTC), or parental adults were removed after 1 week and samples were held for an additional 8 weeks ( 7 day). No progeny development on corn treated with either rate of Diacon IGR+ or the Gravista formulation, no overall ANOVA done, only comparison between the two parental exposure regimes. Data are separated by month, bioassays were done at 1 day (month 0 ), and 3, 6, 9, and 12 months after treatment ${ }^{1}$.

\begin{tabular}{cccccc}
\hline Month & Treatment & Exposure & Progeny & \%Wt. Loss & Frass (g) \\
\hline 0 & UTC & Cont. & $11.4 \pm 3.3 \mathrm{a}$ & $1.18 \pm 0.14 \mathrm{a}$ & $0.56 \pm 0.08 \mathrm{a}$ \\
& & 7 day & $21.4 \pm 3.6 \mathrm{a}$ & $1.06 \pm 0.08 \mathrm{a}$ & $0.46 \pm 0.04 \mathrm{~b}$ \\
\hline \multirow{2}{*}{3} & UTC & Cont. & $0.4 \pm 0.7 \mathrm{~b}$ & $0.66 \pm 0.10 \mathrm{a}$ & $0.34 \pm 0.05 \mathrm{a}$ \\
& & 7 day & $8.2 \pm 0.4 \mathrm{a}$ & $0.51 \pm 0.10 \mathrm{a}$ & $0.20 \pm 0.04 \mathrm{~b}$ \\
\hline \multirow{2}{*}{6} & UTC & Cont. & $4.8 \pm 1.8 \mathrm{a}$ & $0.78 \pm 0.14 \mathrm{a}$ & $0.48 \pm 0.05 \mathrm{a}$ \\
& & 7 day & $6.2 \pm 2.4 \mathrm{a}$ & $0.33 \pm 0.10 \mathrm{~b}$ & $0.18 \pm 0.06 \mathrm{~b}$ \\
\hline \multirow{2}{*}{9} & UTC & Cont. & $18.8 \pm 3.8 \mathrm{a}$ & $0.68 \pm 0.18 \mathrm{a}$ & $0.08 \pm 0.02 \mathrm{a}$ \\
& & 7 day & $14.0 \pm 3.6 \mathrm{a}$ & $0.33 \pm 0.09 \mathrm{~b}$ & $0.06 \pm 0.06 \mathrm{a}$ \\
\hline \multirow{2}{*}{12} & UTC & Cont. & $35.8 \pm 6.1 \mathrm{a}$ & $1.58 \pm 0.22 \mathrm{a}$ & $0.46 \pm 0.09 \mathrm{a}$ \\
& & 7 day & $28.8 \pm 3.4 \mathrm{a}$ & $0.49 \pm 0.06 \mathrm{~b}$ & $0.20 \pm 0.04 \mathrm{~b}$ \\
\hline
\end{tabular}

${ }^{1}$ Means for exposure for progeny, weight loss, and frass weight, followed by the same lowercase letter, are not significantly different $(p \geq 0.05$, Proc $t$-test, SAS).

Survival of parental T. castaneum was strongly correlated with progeny production, but even when there was parental survival, there was no progeny production, and also variation when survival was $100 \%$ (Figure $4 \mathrm{~A}$ ). The relatively low progeny production on corn perhaps contributed to the variation, which was not surprising given the low reproductive capacity of this species on whole grain kernels. Survival of parental S. zeamais was also correlated with progeny production, but similar to S. oryzae on wheat, there was considerable variation, where parental survival ranged from $20 \%$ to $80 \%$, and also variation when survival was $100 \%$ (Figure 4B). Progeny production of both species in the 7 day exposures was correlated with production in the continuous exposures, with more variation in S. zeamais, as reflected by the low $r$ values (Figure 5A,B). Sample weight loss and frass weight was correlated between the two parental exposure regimes for both species, with stronger correlation and greater $r$ values for T. castaneum compared to S. zeamais (Figure 5C-F). Progeny production of both species was strongly correlated with sample weight loss (Figure 6A,B) and frass weight (Figure 6C,D), and frass weight was correlated with sample weight loss (Figure 6D,E), but with lower $r$ values for T. castaneum compared to $S$. zeamais. The $r$ values for all correlations in Figure 6 ranged from 0.544 to 0.866 . 
Table 10. Number of $F_{1}$ adult progeny, \% of sample weight loss due to insect feeding, and feeding damage (frass) (mean \pm SE for all) from exposure of ten mixed-sex parental adult S. zeamais exposed on $\sim 80 \mathrm{~g}$ of untreated corn (UTC) wheat or corn treated with the low rate of Diacon IGR+ (Ldiacon IGR +, 0.5 ppm deltamethrin +1.25 ppm methoprene), the high rate of Diacon IGR+ (Hdiacon IGR+, $1.0 \mathrm{ppm}+2.5 \mathrm{ppm}$ methoprene), or the Gravista formulation (methoprene + deltamethrin + piperonyl butoxide synergist). Parental adults were either continuously exposed for about 8 weeks (Cont.) or were removed after 1 week and samples were held for an additional 8 weeks ( 7 day). Data are separated by month, bioassays were done at 1 day (month 0 ), and 3, 6, 9, and 12 months after treatment ${ }^{1,2}$.

\begin{tabular}{|c|c|c|c|c|c|}
\hline Month & Treatment & Exposure & Progeny & \%Wt. Loss & Frass (g) \\
\hline \multirow[t]{8}{*}{0} & UTC & Cont. & $23.2 \pm 6.3 a$ & $1.86 \pm 0.86 a$ & $0.46 \pm 0.08 a$ \\
\hline & Ldiacon IGR+ & & $4.0 \pm 1.6 \mathrm{~b}$ & $0.44 \pm 0.10 \mathrm{ab}$ & $0.05 \pm 0.03 b$ \\
\hline & Hdiacon IGR+ & & $2.0 \pm 1.8 \mathrm{~b}$ & $0.25 \pm 0.06 b$ & $0.02 \pm 0.02 b$ \\
\hline & Gravista & & $0.4 \pm 0.2 b$ & $0.29 \pm 0.07 b$ & $0.00 \pm 0.00 \mathrm{~b}$ \\
\hline & UTC & 7 day & $14.6 \pm 5.8 \mathrm{a}$ & $0.54 \pm 0.13 a$ & $0.20 \pm 0.07 a$ \\
\hline & Ldiacon IGR+ & & $7.6 \pm 3.2 b$ & $0.39 \pm 0.07 \mathrm{ab}$ & $0.02 \pm 0.02 b$ \\
\hline & Hdiacon IGR+ & & $2.0 \pm 1.1 \mathrm{~b}$ & $0.22 \pm 0.04 b$ & $0.00 \pm 0.00 \mathrm{~b}$ \\
\hline & Gravista & & $0.0 \pm 0.0 \mathrm{~b}$ & $0.09 \pm 0.03 b$ & $0.00 \pm 0.00 \mathrm{~b}$ \\
\hline \multirow[t]{8}{*}{3} & UTC & Cont. & $14.6 \pm 4.3 \mathrm{a}$ & $0.87 \pm 0.16 \mathrm{ab}$ & $0.32 \pm 0.09 b$ \\
\hline & Ldiacon IGR+ & & $11.8 \pm 3.2 \mathrm{a}$ & $1.42 \pm 0.19 \mathrm{a}$ & $0.52 \pm 0.07 \mathrm{a}$ \\
\hline & Hdiacon IGR+ & & $13.2 \pm 4.0 \mathrm{a}$ & $0.52 \pm 0.11 b$ & $0.10 \pm 0.05 c$ \\
\hline & Gravista & & $6.0 \pm 3.9 \mathrm{a}$ & $0.41 \pm 0.52 b$ & $0.12 \pm 0.04 c$ \\
\hline & UTC & 7 day & $27.6 \pm 14.2 \mathrm{a}$ & $0.97 \pm 0.12 a$ & $0.42 \pm 0.07 a$ \\
\hline & Ldiacon IGR+ & & $21.6 \pm 3.8 \mathrm{ab}$ & $0.56 \pm 0.15 \mathrm{ab}$ & $0.22 \pm 0.04 b$ \\
\hline & Hdiacon IGR+ & & $18.2 \pm 7.1 \mathrm{ab}$ & $0.58 \pm 0.20 \mathrm{ab}$ & $0.02 \pm 0.02 c$ \\
\hline & Gravista & & $4.8 \pm 1.6 \mathrm{~b}$ & $0.23 \pm 0.0 .8 b$ & $0.08 \pm 0.05 c$ \\
\hline \multirow[t]{8}{*}{6} & UTC & Cont. & $64.6 \pm 18.6 \mathrm{a}$ & $1.80 \pm 0.43 a$ & $0.94 \pm 0.24 \mathrm{a}$ \\
\hline & Ldiacon IGR+ & & $36.6 \pm 3.4 \mathrm{ab}$ & $0.90 \pm 0.18 b$ & $0.54 \pm 0.09 \mathrm{ab}$ \\
\hline & Hdiacon IGR+ & & $14.0 \pm 6.7 \mathrm{~b}$ & $0.37 \pm 0.16 b$ & $0.24 \pm 0.10 b$ \\
\hline & Gravista & & $15.8 \pm 3.4 b$ & $0.52 \pm 0.14 b$ & $0.34 \pm 0.04 b$ \\
\hline & UTC & 7 day & $13.0 \pm 3.4 \mathrm{a}$ & $0.26 \pm 0.08 \mathrm{ab}$ & $0.14 \pm 0.04 \mathrm{a}$ \\
\hline & Ldiacon IGR+ & & $14.4 \pm 5.3 \mathrm{a}$ & $0.33 \pm 0.13 a$ & $0.12 \pm 0.06 \mathrm{ab}$ \\
\hline & Hdiacon IGR+ & & $4.4 \pm 1.2 \mathrm{a}$ & $0.06 \pm 0.04 b$ & $0.00 \pm 0.00 b$ \\
\hline & Gravista & & $4.6 \pm 2.2 \mathrm{a}$ & $0.08 \pm 0.06 \mathrm{ab}$ & $0.04 \pm 0.04 \mathrm{ab}$ \\
\hline \multirow[t]{8}{*}{9} & UTC & Cont. & $43.0 \pm 11.5 \mathrm{ab}$ & $0.85 \pm 0.10 \mathrm{ab}$ & $0.40 \pm 0.12 \mathrm{ab}$ \\
\hline & Ldiacon IGR+ & & $67.2 \pm 7.3 \mathrm{a}$ & $1.08 \pm 0.14 \mathrm{a}$ & $0.58 \pm 0.09 a$ \\
\hline & Hdiacon IGR+ & & $14.0 \pm 6.6 b$ & $0.94 \pm 0.21 \mathrm{ab}$ & $0.44 \pm 0.16 \mathrm{ab}$ \\
\hline & Gravista & & $15.8 \pm 3.5 \mathrm{~b}$ & $0.65 \pm 0.07 \mathrm{~b}$ & $0.24 \pm 0.02 b$ \\
\hline & UTC & 7 day & $58.6 \pm 13.9 \mathrm{a}$ & $1.40 \pm 0.29 \mathrm{a}$ & $0.48 \pm 0.13 a$ \\
\hline & Ldiacon IGR+ & & $41.0 \pm 6.7 \mathrm{ab}$ & $0.90 \pm 0.13 \mathrm{ab}$ & $0.34 \pm 0.04 \mathrm{ab}$ \\
\hline & Hdiacon IGR+ & & $29.0 \pm 4.1 \mathrm{~b}$ & $0.40 \pm 0.09 \mathrm{~b}$ & $0.16 \pm 0.06 b$ \\
\hline & Gravista & & $28.2 \pm 6.1 b$ & $0.35 \pm 0.11 b$ & $0.12 \pm 0.06 \mathrm{~b}$ \\
\hline \multirow[t]{8}{*}{12} & UTC & Cont. & $94.7 \pm 16.8 \mathrm{a}$ & $3.18 \pm 0.56 a$ & $1.15 \pm 0.18 \mathrm{a}$ \\
\hline & Ldiacon IGR+ & & $47.8 \pm 5.4 b$ & $1.48 \pm 0.20 b$ & $0.80 \pm 0.07 a$ \\
\hline & Hdiacon IGR+ & & $53.8 \pm 17.1 b$ & $1.18 \pm 0.37 b$ & $0.75 \pm 0.22 \mathrm{ab}$ \\
\hline & Gravista & & $36.6 \pm 4.4 \mathrm{~b}$ & $1.19 \pm 0.13 b$ & $0.40 \pm 0.10 b$ \\
\hline & UTC & 7 day & $82.0 \pm 21.7 \mathrm{a}$ & $2.06 \pm 0.41 \mathrm{a}$ & $0.85 \pm 0.20 \mathrm{a}$ \\
\hline & Ldiacon IGR+ & & $35.6 \pm 4.9 \mathrm{~b}$ & $1.45 \pm 0.12 b$ & $0.56 \pm 0.11 \mathrm{ab}$ \\
\hline & Hdiacon IGR+ & & $22.2 \pm 8.9 \mathrm{~b}$ & $0.76 \pm 0.23 c$ & $0.28 \pm 0.13 b$ \\
\hline & Gravista & & $36.8 \pm 5.3 b$ & $1.19 \pm 0.24 b c$ & $0.38 \pm 0.09 b$ \\
\hline
\end{tabular}

${ }^{1}$ Means within columns followed by the same lowercase letter are not significantly different $(p \geq 0.05$, Proc Mixed, SAS, Tukey's Honest Significant Difference Test). Data separated by species. 

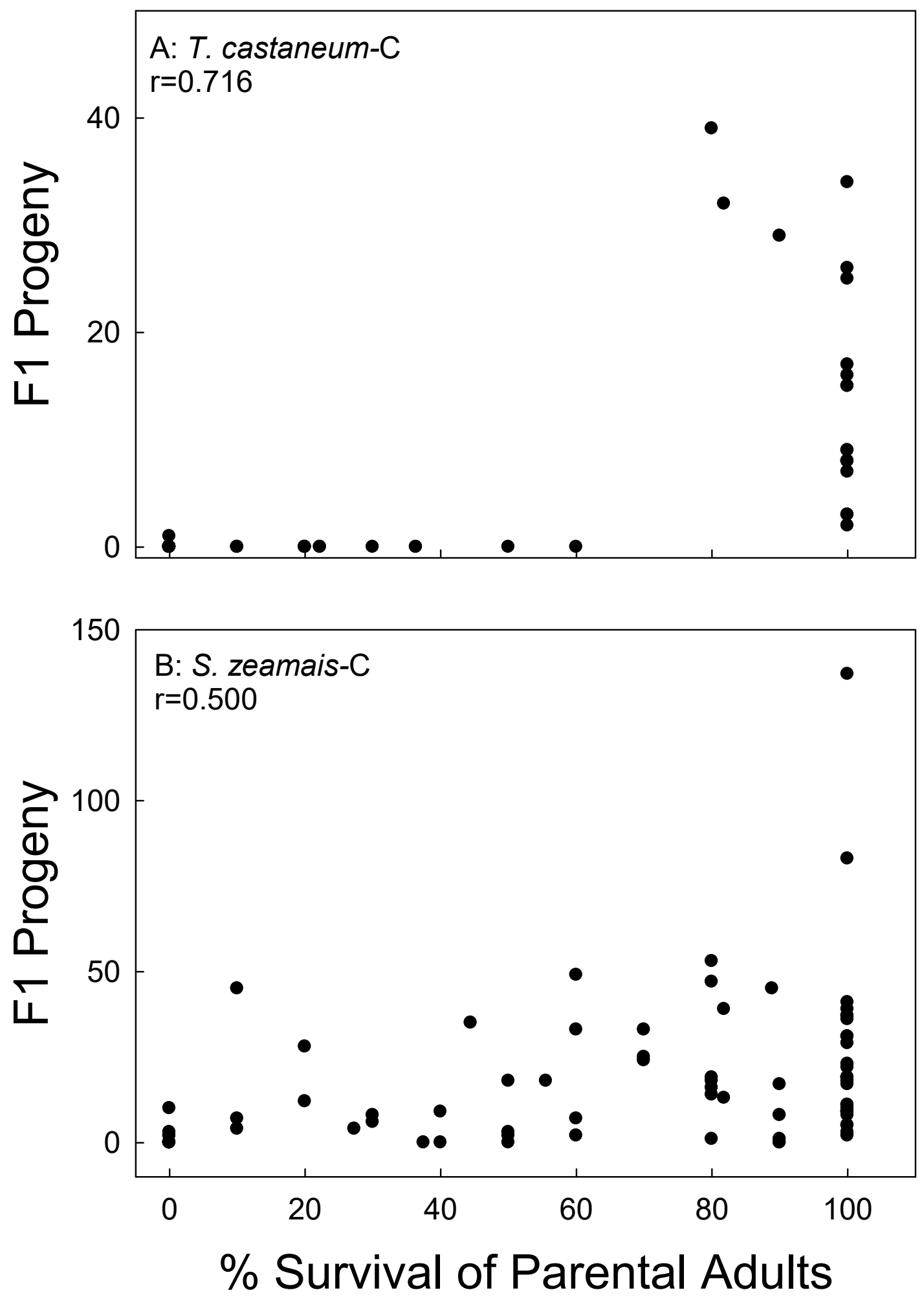

Figure 4. Correlation of parental survival with F1 progeny production of T. castaneum (A) and S. zeamais (B) on corn (C). Data combined for treatments and all bioassay months. 

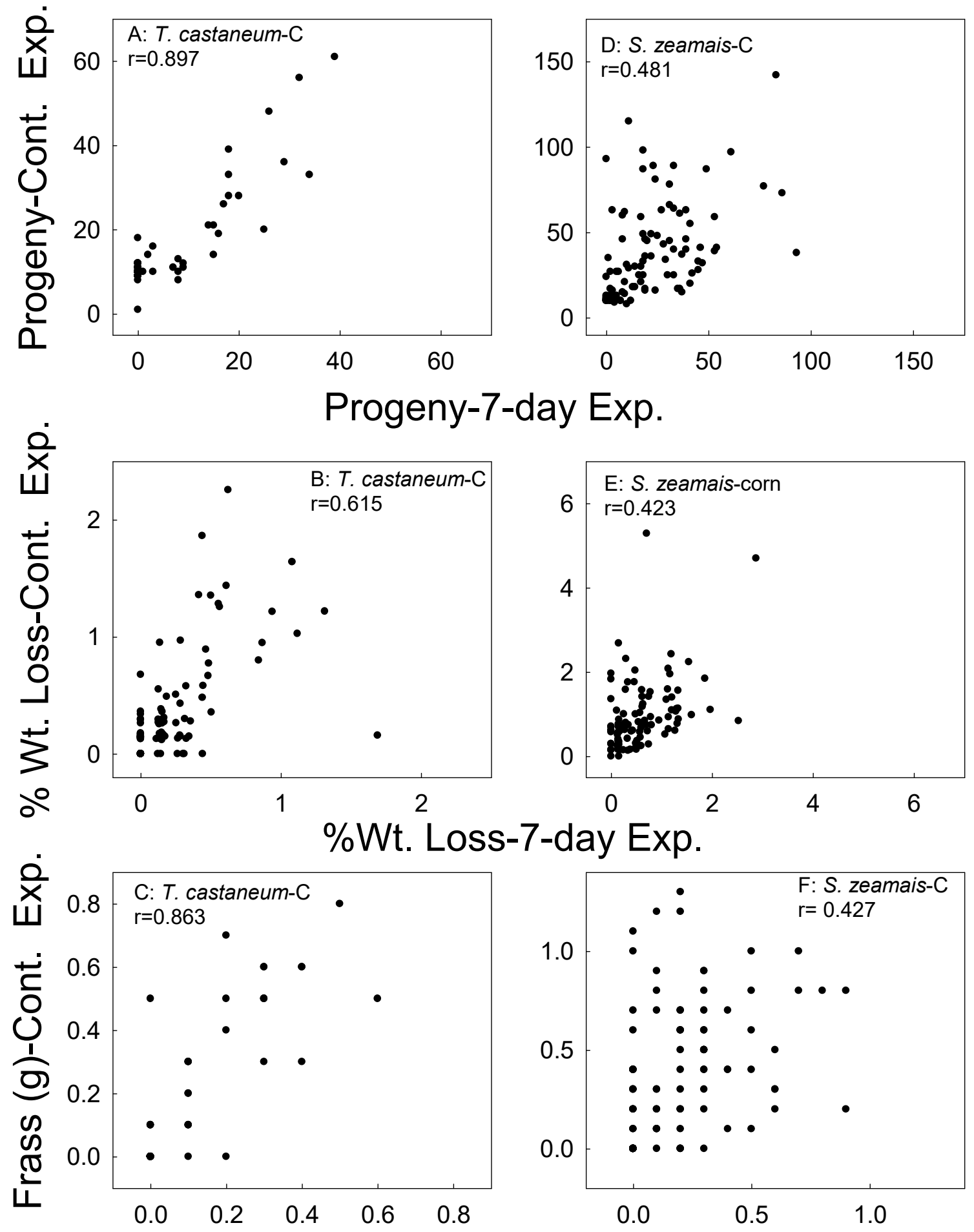

Frass (g)-7-day Exp.

Figure 5. Correlation of $F_{1}$ progeny, sample weight loss, and frass weight in the corn (C) samples whereby parental adults were exposed for 7 days versus the continual exposures of parental adults for T. castaneum (A-C) and S. zeamais (D-F). Data combined for all treatments and all bioassay months. 

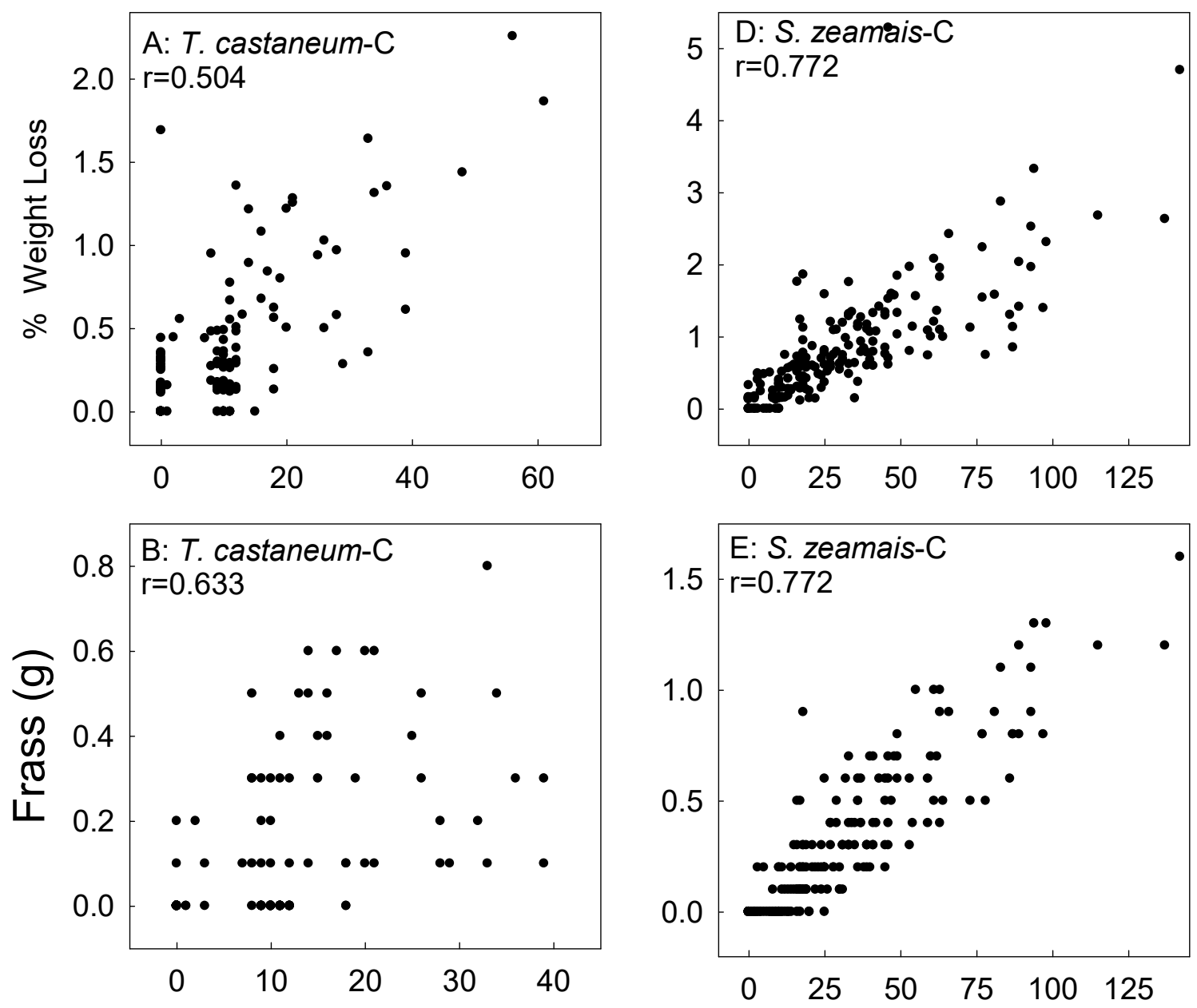

F1 Progeny
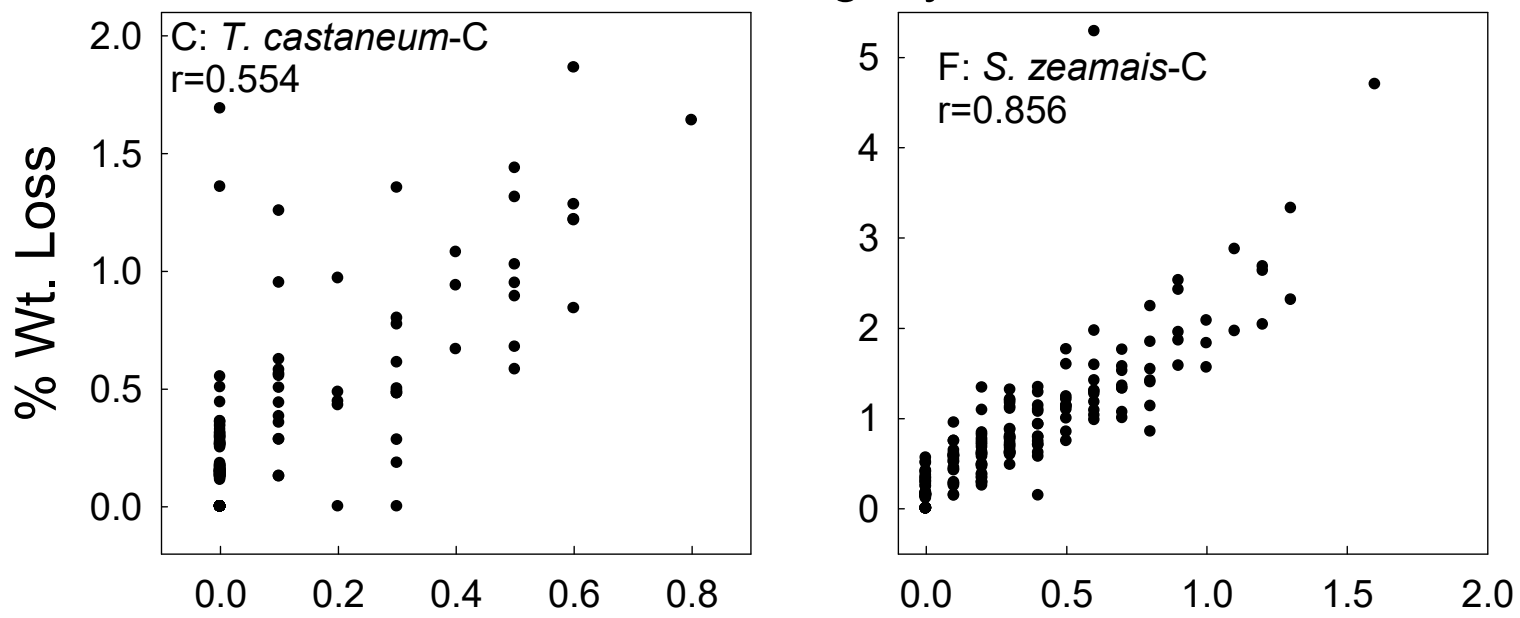

Frass (g)

Figure 6. Correlation of corn (C) sample weight loss and frass weight with $\mathrm{F}_{1}$ progeny of $T$. castaneum $(\mathbf{A}, \mathbf{B})$, sample weight loss with frass weight $(\mathbf{C})$, sample weight loss and frass weight with $\mathrm{F}_{1}$ progeny of $S$. zeamais $(\mathbf{D}, \mathbf{E})$, and sample weight loss with frass weight $(\mathbf{F})$. Data for the two parental exposure regimes combined, data for all treatments and all bioassay months combined. 


\subsection{Brown Rice}

The ANOVA analyses for R. dominica and S. oryzae after the 7 day exposures on untreated and treated brown rice are shown in Table 11. Main effects month, treatment, and the interactions were generally significant for the percentage of live adults, adults that were knocked down, or adults that were dead for R. dominica, except for main effect month for knockdown of exposed adults. Main effects month and treatment were significant for $S$. oryzae for live and dead adults, but treatment was not significant for knockdown. Some but not all interactions were significant for S. oryzae. Survival of R. dominica on untreated brown rice was $100 \%$ except for month 9 . There were generally no live adults in any of the chemical treatments except for the low rate of Diacon IGR+, and only one instance where live adults were present after $7 \mathrm{~d}$ of exposure on the brown rice treated with the Gravista product. There were adult $R$. dominica that were knocked down or dead in the treated brown rice at all bioassay points, and in most comparisons, the treatment values were different from controls, but there were no differences among the three insecticide treatments for percentage knocked down or dead. Except for month 3, the percentage of live S. oryzae after the 7 day exposures exceeded $90 \%$ in all three insecticide treatments, and were usually not significantly different from the untreated controls or from each other (Table 12). Thus, the percentage of knocked down or dead adults was also low in untreated controls and in the three insecticide treatments.

Table 11. ANOVA Table for main effects month (MO), treatment (TR, untreated controls, two rates of Diacon IGR+, and the Gravista product) for the percentage of adult $R$. dominica and S. oryzae that were alive (Live), knocked down (KD), or dead (D) after 7 days of exposure on brown rice.

\begin{tabular}{cllrrr}
\hline Species & Response & Variable & \multicolumn{1}{c}{$\boldsymbol{F}$} & \multicolumn{1}{c}{ df } & \multicolumn{1}{c}{$p$} \\
\hline R. dominica & Live & MO & 4.4 & 4,79 & 0.003 \\
& & TRT & 1396.3 & 3,79 & $<0.001$ \\
& & MO*TRT & 2.6 & 12,79 & 0.006 \\
\cline { 2 - 6 } & KD & MO & 1.9 & 4,79 & 0.115 \\
& TRT & 21.9 & 3,79 & $<0.001$ \\
& & MO*TRT & 2.4 & 12,79 & 0.011 \\
\cline { 2 - 6 } S. oryzae & Dead & MO & 2.6 & 4,79 & 0.048 \\
& & TRT & 297.0 & 3,79 & $<0.001$ \\
& & MO*TRT & 1.3 & 12,79 & 0.210 \\
\hline & MO & 16.7 & 4,78 & $<0.001$ \\
& & TRT & 3.5 & 3,78 & 0.012 \\
& KD & MO*TRT & 2.4 & 12,78 & 0.012 \\
\hline & MO & 14.3 & 4,78 & $<0.001$ \\
& & TRT & 2.4 & 3,78 & 0.076 \\
& & MO*TRT & 2.4 & 12,78 & 0.010 \\
\cline { 2 - 6 } & Dead & MO & 6.0 & 4,78 & $<0.001$ \\
& & TRT & 3.6 & 3,78 & 0.016 \\
& & MO*TRT & 1.2 & 12,78 & 0.287 \\
\hline
\end{tabular}


Table 12. Percentage (means $\pm \mathrm{SE}$ ) of $R$. dominica and S. oryzae live, knocked down (KD), or dead (means \pm SE) seven days after exposure on untreated brown rice (UTC) or brown rice treated with $0.5 \mathrm{ppm}$ deltamethrin + 1.25 ppm methoprene $(0.5 \mathrm{ppm} \mathrm{D} \mathrm{+} 1.25 \mathrm{ppm} \mathrm{M}), 1.0 \mathrm{ppm}+2.5 \mathrm{ppm}$ methoprene (1.5 ppm D + 2.5 ppm M), or the Gravista (methoprene $(\mathrm{M})+$ deltamethrin $(\mathrm{D})+$ piperonyl butoxide synergist (PBO). Data are separated by month, bioassays were done at 0 months (1 day), and 3, 6, and 12 months after treatment ${ }^{1}$.

\begin{tabular}{|c|c|c|c|c|c|}
\hline Month & Treatment & Species & $\%$ Live & $\% \mathrm{KD}$ & \% Dead \\
\hline \multirow[t]{8}{*}{0} & UTC & R. dominica & $100.0 \pm 0.0 \mathrm{a}$ & $0.0 \pm 0.0 \mathrm{~b}$ & $0.0 \pm 0.0 \mathrm{~b}$ \\
\hline & LDiacon IGR+ & & $0.0 \pm 0.0 \mathrm{~b}$ & $29.7 \pm 3.4 \mathrm{a}$ & $70.3 \pm 3.4 \mathrm{a}$ \\
\hline & HDiacon IGR+ & & $0.0 \pm 0.0 \mathrm{~b}$ & $18.0 \pm 6.6 \mathrm{a}$ & $82.0 \pm 6.6 \mathrm{a}$ \\
\hline & Gravista & & $0.0 \pm 0.0 \mathrm{~b}$ & $29.3 \pm 5.1 \mathrm{a}$ & $70.7 \pm 5.1 \mathrm{a}$ \\
\hline & UTC & S. oryzae & $100.0 \pm 0.0 \mathrm{a}$ & $0.0 \pm 0.0 \mathrm{a}$ & $0.0 \pm 0.0 \mathrm{a}$ \\
\hline & LDiacon IGR+ & & $94.2 \pm 3.9 \mathrm{a}$ & $0.0 \pm 0.0 \mathrm{a}$ & $5.8 \pm 3.9 \mathrm{a}$ \\
\hline & HDiacon IGR+ & & $92.0 \pm 5.8 \mathrm{a}$ & $0.0 \pm 0.0 \mathrm{a}$ & $8.0 \pm 1.4 \mathrm{a}$ \\
\hline & Gravista & & $93.7 \pm 2.6 \mathrm{a}$ & $0.0 \pm 0.0 \mathrm{a}$ & $6.3 \pm 2.6 \mathrm{a}$ \\
\hline \multirow[t]{9}{*}{3} & UTC & R. dominica & $100.0 \pm 0.0 \mathrm{a}$ & $0.0 \pm 0.0 \mathrm{~b}$ & $0.0 \pm 0.0 \mathrm{~b}$ \\
\hline & LDiacon IGR+ & & $0.0 \pm 0.0 \mathrm{~b}$ & $30.0 \pm 8.4 \mathrm{a}$ & $70.0 \pm 8.4 \mathrm{a}$ \\
\hline & HDiacon IGR+ & & $0.0 \pm 0.0 \mathrm{~b}$ & $16.0 \pm 5.1 \mathrm{a}$ & $84.0 \pm 5.1 \mathrm{a}$ \\
\hline & Gravista & & $0.0 \pm 0.0 \mathrm{~b}$ & $18.0 \pm 3.7 \mathrm{a}$ & $82.0 \pm 3.7 \mathrm{a}$ \\
\hline & UTC & S. oryzae & $100.0 \pm 0.0 \mathrm{a}$ & $0.0 \pm 0.0 \mathrm{~b}$ & $0.0 \pm 0.0 \mathrm{~b}$ \\
\hline & LDiacon IGR+ & & $78.0 \pm 2.0 \mathrm{~b}$ & $8.0 \pm 3.7 \mathrm{a}$ & $14.0 \pm 2.4 \mathrm{a}$ \\
\hline & HDiacon IGR+ & & $74.1 \pm 7.3 \mathrm{~b}$ & $18.1 \pm 6.0 \mathrm{a}$ & $7.8 \pm 5.8 \mathrm{ab}$ \\
\hline & Gravista & & $75.8 \pm 4.9 \mathrm{~b}$ & $10.0 \pm 6.3 a$ & $12.2 \pm 2.4 \mathrm{a}$ \\
\hline & UTC & & & & \\
\hline \multirow[t]{8}{*}{6} & LDiacon IGR+ & R. dominica & $100.0 \pm 0.0 \mathrm{a}$ & $0.0 \pm 0.0 \mathrm{~b}$ & $0.0 \pm 0.0 \mathrm{~b}$ \\
\hline & HDiacon IGR+ & & $12.0 \pm 12.0 \mathrm{~b}$ & $36.9 \pm 11.5 \mathrm{a}$ & $51.1 \pm 7.5 \mathrm{a}$ \\
\hline & Gravista & & $0.0 \pm 0.0 \mathrm{~b}$ & $23.5 \pm 5.7 \mathrm{a}$ & $76.5 \pm 5.7 \mathrm{a}$ \\
\hline & & & $0.0 \pm 0.0 \mathrm{~b}$ & $25.5 \pm 5.7 \mathrm{a}$ & $74.5 \pm 5.7 \mathrm{a}$ \\
\hline & UTC & S. oryzae & $100.0 \pm 0.0 \mathrm{a}$ & $0.0 \pm 0.0 \mathrm{a}$ & $0.0 \pm 0.0 \mathrm{a}$ \\
\hline & LDiacon IGR+ & & $100.0 \pm 0.0 \mathrm{a}$ & $0.0 \pm 0.0 \mathrm{a}$ & $0.0 \pm 0.0 \mathrm{a}$ \\
\hline & HDiacon IGR+ & & $100.0 \pm 0.0 \mathrm{a}$ & $0.0 \pm 0.0 \mathrm{a}$ & $0.0 \pm 0.0 \mathrm{a}$ \\
\hline & Gravista & & $100.0 \pm 0.0 \mathrm{a}$ & $0.0 \pm 0.0 \mathrm{a}$ & $0.0 \pm 0.0 \mathrm{a}$ \\
\hline \multirow[t]{8}{*}{9} & UTC & R. dominica & $87.9 \pm 4.6 \mathrm{a}$ & $2.3 \pm 2.3 b$ & $9.8 \pm 4.1 \mathrm{~b}$ \\
\hline & LDiacon IGR+ & & $21.4 \pm 3.4 b$ & $2.0 \pm 2.0 \mathrm{~b}$ & $76.5 \pm 3.8 \mathrm{a}$ \\
\hline & HDiacon IGR+ & & $0.0 \pm 0.0 \mathrm{c}$ & $6.0 \pm 4.0 \mathrm{~b}$ & $94.0 \pm 4.0 \mathrm{a}$ \\
\hline & Gravista & & $3.7 \pm 2.3 c$ & $37.0 \pm 10.4 \mathrm{a}$ & $71.3 \pm 8.1 \mathrm{a}$ \\
\hline & UTC & S. oryzae & $97.8 \pm 2.2 \mathrm{a}$ & $0.0 \pm 0.0 \mathrm{a}$ & $2.2 \pm 2.2 \mathrm{a}$ \\
\hline & LDiacon IGR+ & & $98.0 \pm 2.0 \mathrm{a}$ & $0.0 \pm 0.0 \mathrm{a}$ & $2.0 \pm 2.0 \mathrm{a}$ \\
\hline & HDiacon IGR+ & & $96.0 \pm 2.4 \mathrm{a}$ & $0.0 \pm 0.0 \mathrm{a}$ & $4.0 \pm 2.4 \mathrm{a}$ \\
\hline & Gravista & & $96.0 \pm 4.0 \mathrm{a}$ & $0.0 \pm 0.0 \mathrm{a}$ & $4.0 \pm 4.0 \mathrm{a}$ \\
\hline \multirow[t]{8}{*}{12} & UTC & R. dominica & $100.0 \pm 0.0 \mathrm{a}$ & $0.0 \pm 0.0 \mathrm{a}$ & $0.0 \pm 0.0 \mathrm{a}$ \\
\hline & LDiacon IGR+ & & $0.0 \pm 0.0 \mathrm{~b}$ & $26.0 \pm 4.0 \mathrm{~b}$ & $74.0 \pm 0.0 \mathrm{~b}$ \\
\hline & HDiacon IGR+ & & $0.0 \pm 0.0 \mathrm{~b}$ & $16.0 \pm 5.1 b$ & $84.0 \pm 5.1 \mathrm{~b}$ \\
\hline & Gravista & & $0.0 \pm 0.0 \mathrm{~b}$ & $20.0 \pm 7.1 \mathrm{~b}$ & $80.0 \pm 7.1 \mathrm{~b}$ \\
\hline & UTC & S. oryzae & $100.0 \pm 0.0 \mathrm{a}$ & $0.0 \pm 0.0 \mathrm{a}$ & $0.0 \pm 0.0 \mathrm{a}$ \\
\hline & LDiacon IGR+ & & $98.0 \pm 2.0 \mathrm{a}$ & $0.0 \pm 0.0 \mathrm{a}$ & $2.0 \pm 2.0 \mathrm{a}$ \\
\hline & HDiacon IGR+ & & $100.0 \pm 0.0 \mathrm{a}$ & $0.0 \pm 0.0 \mathrm{a}$ & $0.0 \pm 0.0 \mathrm{a}$ \\
\hline & Gravista & & $96.0 \pm 4.0 \mathrm{a}$ & $0.0 \pm 0.0 \mathrm{a}$ & $4.0 \pm 4.0 \mathrm{a}$ \\
\hline
\end{tabular}

${ }^{1}$ Means within columns followed by the same lowercase letter are not significantly different $(p \geq 0.05$, Proc Mixed, SAS, Tukey's Honest Significant Difference Test). Data separated by species.

The ANOVA Table for F1 progeny production, sample weight loss, and frass weight for R. dominica and S. oryzae are presented in Table 13. Main effects treatment and exposure were significant for progeny production of $R$. dominica, but not month, while all main effects were significant for sample 
weight loss and frass rate. About half of the interactions were significant. Main effect treatment was not significant for S. oryzae for any of the three analysis variables.

Table 13. ANOVA Table for main effects month (MO), treatment (untreated controls, two rates of Diacon IGR+, and the Gravista formulation), and count (CT, parental insects removed after 7 days or left continuously on the corn for 8 weeks), and all associated interactions, for R. dominica and S. oryzae $\mathrm{F}_{1}$ progeny, $\%$ of sample weight loss, and weight in grams of feeding damage ${ }^{1}$.

\begin{tabular}{|c|c|c|c|c|c|}
\hline Species & Response & Variable & $F$ & df & $p$ \\
\hline \multirow[t]{21}{*}{ R. dominica } & \multirow[t]{7}{*}{$\mathrm{F}_{1}$ Progeny } & $\mathrm{MO}$ & 2.2 & 4,149 & 0.067 \\
\hline & & TRT & 128.5 & 3,149 & $<0.001$ \\
\hline & & $\mathrm{CT}$ & 9.0 & 1,149 & 0.003 \\
\hline & & MO*TRT & 5.6 & 12,149 & $<0.001$ \\
\hline & & $\mathrm{MO}^{*} \mathrm{CT}$ & 2.7 & 4,149 & 0.035 \\
\hline & & $\mathrm{TRT}^{*} \mathrm{CT}$ & 0.2 & 3,149 & 0.997 \\
\hline & & $\mathrm{MO}^{*} \mathrm{TRT}^{*} \mathrm{CT}$ & 2.9 & 12,149 & 0.001 \\
\hline & \multirow[t]{7}{*}{ \% Weight Loss } & $\mathrm{MO}$ & 9.3 & 4,148 & $<0.001$ \\
\hline & & TRT & 109.5 & 3,148 & $<0.001$ \\
\hline & & $\mathrm{CT}$ & 12.6 & 1,148 & $<0.001$ \\
\hline & & $\mathrm{MO}^{*} \mathrm{TRT}$ & 2.9 & 12,148 & 0.001 \\
\hline & & $\mathrm{MO}^{*} \mathrm{CT}$ & 2.7 & 4,148 & 0.059 \\
\hline & & $\mathrm{TRT}^{*} \mathrm{CT}$ & 2.5 & 3,148 & 0.063 \\
\hline & & $\mathrm{MO}^{*} \mathrm{TRT}^{*} \mathrm{CT}$ & 4.4 & 12,148 & $<0.001$ \\
\hline & \multirow[t]{7}{*}{ Frass Weight } & $\mathrm{MO}$ & 3.4 & 4,149 & 0.013 \\
\hline & & TRT & 115.2 & 3,149 & $<0.001$ \\
\hline & & $\mathrm{CT}$ & 16.2 & 1,149 & $<0.001$ \\
\hline & & MO*TRT & 3.0 & 12,149 & $<0.001$ \\
\hline & & $\mathrm{MO}^{*} \mathrm{CT}$ & 2.3 & 4,149 & 0.001 \\
\hline & & $\mathrm{TRT}^{*} \mathrm{CT}$ & 15.1 & 3,149 & $<0.001$ \\
\hline & & $\mathrm{MO}^{*} \mathrm{TRT}^{*} \mathrm{CT}$ & 2.2 & 12,149 & 0.013 \\
\hline \multirow[t]{21}{*}{ S. oryzae } & \multirow[t]{7}{*}{$\mathrm{F}_{1}$ Progeny } & $\mathrm{MO}$ & 37.5 & 3,119 & $<0.001$ \\
\hline & & TRT & 0.3 & 3,119 & 0.856 \\
\hline & & $\mathrm{CT}$ & 14.1 & 1,155 & $<0.001$ \\
\hline & & $\mathrm{MO}^{*} \mathrm{TRT}$ & 5.5 & 9,119 & 0.004 \\
\hline & & $\mathrm{MO}^{*} \mathrm{CT}$ & 12.4 & 3,119 & 0.002 \\
\hline & & $\mathrm{TRT}^{*} \mathrm{CT}$ & 0.2 & 3,119 & 0.885 \\
\hline & & $\mathrm{MO}^{*} \mathrm{TRT}^{*} \mathrm{CT}$ & 1.9 & 9,119 & 0.056 \\
\hline & \multirow[t]{7}{*}{$\%$ Weight Loss } & $\mathrm{MO}$ & 78.3 & 3,115 & $<0.001$ \\
\hline & & TRT & 2.0 & 3,115 & 0.118 \\
\hline & & $\mathrm{CT}$ & 7.4 & 1,115 & 0.007 \\
\hline & & $\mathrm{MO}^{*} \mathrm{TRT}$ & 3.9 & 9,115 & 0.001 \\
\hline & & $\mathrm{MO}{ }^{*} \mathrm{CT}$ & 12.6 & 3,115 & $<0.001$ \\
\hline & & $\mathrm{TRT}^{*} \mathrm{CT}$ & 2.9 & 3,115 & 0.037 \\
\hline & & $\mathrm{MO}^{*} \mathrm{TRT}^{*} \mathrm{CT}$ & 4.8 & 9,115 & $<0.001$ \\
\hline & \multirow[t]{7}{*}{ Frass Weight } & $\mathrm{MO}$ & 22.7 & 3,118 & $<0.001$ \\
\hline & & TRT & 1.6 & 3,118 & 0.186 \\
\hline & & $\mathrm{CT}$ & 0.0 & 1,118 & 0.973 \\
\hline & & MO*TRT & 9.0 & 9,118 & $<0.001$ \\
\hline & & $\mathrm{MO} * \mathrm{CT}$ & 2.0 & 3,118 & 0.121 \\
\hline & & $\mathrm{TRT}^{*} \mathrm{CT}$ & 3.4 & 3,118 & 0.032 \\
\hline & & $\mathrm{MO}^{*} \mathrm{TRT}^{*} \mathrm{CT}$ & 5.6 & 9,118 & $<0.001$ \\
\hline
\end{tabular}

${ }^{1}$ S. oryzae samples at 12 months could not be processed due to extensive progeny production and fungal development on all samples, controls and treatments.

There was no progeny production of $R$. dominica in any of the three treatments, similar to the results for the exposures on wheat, thus, data were analyzed only by exposure method for untreated controls (Table 14). There were no differences in progeny production, and only one occasion each 
when weight loss and frass was greater in the continual parental exposures versus the 7 day exposures. Since the overall ANOVA showed no treatment effects for $S$. oryzae on brown rice, data for treatment were combined and analyzed by month (Table 15). Samples for month 12 could not be processed because the progeny numbers were so great that the rice was clumped with heavy fungal development. Progeny production ranged from 94.4 to 432.0, and was greater in the continual parental exposures compared to the 7 day parental exposures at months 0 and 3 but not at months 6 and 9. Weight loss was greater in the continual exposures at month 0 , but greater in the 7 day exposures at month 9 . Although frass weight was significant in the overall ANOVA, none of the comparisons between continual parental exposure and 7 day parental exposures were different.

Table 14. Number of $F_{1}$ adult progeny, \% of sample weight loss due to insect feeding, and feeding damage (frass) (mean \pm SE for all) from exposure of ten mixed-sex parental adult $R$. dominica exposed continuously for about 8 weeks (Cont.) on $\sim 80 \mathrm{~g}$ of untreated brown rice (UTC), or parental adults were removed after 1 week and samples were held for an additional 8 weeks ( 7 day). No progeny development on brown rice treated with low and high rates of Diacon IGR+ or the Gravista formulation, no overall ANOVA done, only comparison between the two parental exposure regimes. Data are separated by month, bioassays were done at 1 day (month 0 ), and 3, 6, 9, and 12 months after treatment ${ }^{1}$.

\begin{tabular}{llllll}
\hline Month & Treatment & Exposure & Progeny & \%Wt. Loss & Frass (g) \\
\hline 0 & UTC & Cont. & $53.0 \pm 7.7 \mathrm{a}$ & $2.74 \pm 0.53 \mathrm{a}$ & $1.64 \pm 0.29 \mathrm{a}$ \\
& & 7 day & $74.8 \pm 9.8 \mathrm{a}$ & $3.11 \pm 0.49 \mathrm{a}$ & $0.86 \pm 0.21 \mathrm{a}$ \\
\hline 33 & UTC & Cont. & $28.4 \pm 2.5 \mathrm{a}$ & $1.26 \pm 0.27 \mathrm{a}$ & $0.44 \pm 0.12 \mathrm{a}$ \\
& & 7 day & $38.8 \pm 8.9 \mathrm{a}$ & $1.26 \pm 0.33 \mathrm{a}$ & $0.52 \pm 0.19 \mathrm{a}$ \\
\hline 6 & UTC & Cont. & $73.6 \pm 12.0 \mathrm{a}$ & $3.29 \pm 0.31 \mathrm{a}$ & $1.74 \pm 0.30 \mathrm{a}$ \\
& & 7 day & $43.8 \pm 13.2 \mathrm{a}$ & $0.83 \pm 0.25 \mathrm{a}$ & $0.46 \pm 0.14 \mathrm{~b}$ \\
\hline 9 & UTC & Cont. & $25.4 \pm 1.4 \mathrm{a}$ & $1.38 \pm 0.33 \mathrm{a}$ & $0.86 \pm 0.18 \mathrm{a}$ \\
& & 7 day & $37.4 \pm 7.6 \mathrm{a}$ & $1.73 \pm 0.66 \mathrm{a}$ & $0.58 \pm 0.19 \mathrm{a}$ \\
\hline \multirow{2}{*}{12} & UTC & Cont. & $94.0 \pm 23.4 \mathrm{a}$ & $2.82 \pm 0.77 \mathrm{a}$ & $1.84 \pm 0.53 \mathrm{a}$ \\
& & 7 day & $50.0 \pm 14.3 \mathrm{a}$ & $1.22 \pm 0.30 \mathrm{~b}$ & $0.60 \pm 0.19 \mathrm{~b}$ \\
\hline
\end{tabular}

${ }^{1}$ Means for exposure for progeny, weight loss, and frass weight, followed by the same lowercase letter, are not significantly different $(p \geq 0.05$, Proc $t$-test, SAS).

Table 15. Data for S. oryzae combined for treatments since overall ANOVA showed no treatment effect. Number of $F_{1}$ adult progeny, $\%$ of sample weight loss due to insect feeding, and feeding damage (frass) (mean \pm SE for all) from exposure of ten mixed-sex parental adult $S$. oryzae exposed continuously for about 8 weeks (Cont.) on $\sim 80 \mathrm{~g}$ of untreated brown rice, or adults removed after 7 days of exposure (7 day). Only comparison between the two parental exposure regimes were done. Data are separated by month, bioassays were done at 1 day (month 0 ), and 3, 6, 9 months after treatment ${ }^{1}$.

\begin{tabular}{cccrc}
\hline Month & Exposure & Progeny & \%Wt. Loss & Frass (g) \\
\hline 0 & Cont. & $462.0 \pm 46.9 \mathrm{a}$ & $10.44 \pm 0.90 \mathrm{a}$ & $1.18 \pm 0.10 \mathrm{a}$ \\
& 7 day & $208.2 \pm 27.0 \mathrm{~b}$ & $5.85 \pm 1.10 \mathrm{~b}$ & $1.17 \pm 0.19 \mathrm{a}$ \\
\hline 3 & Cont. & $141.3 \pm 14.2 \mathrm{a}$ & $1.62 \pm 0.24 \mathrm{a}$ & $0.66 \pm 0.15 \mathrm{a}$ \\
& 7 day & $94.4 \pm 6.5 \mathrm{~b}$ & $1.28 \pm 0.12 \mathrm{a}$ & $0.42 \pm 0.04 \mathrm{a}$ \\
\hline 6 & Cont. & $346.6 \pm 45.6 \mathrm{a}$ & $2.88 \pm 0.52 \mathrm{a}$ & $0.88 \pm 0.10 \mathrm{a}$ \\
& 7 day & $304.0 \pm 37.2 \mathrm{a}$ & $3.01 \pm 0.55 \mathrm{a}$ & $0.79 \pm 0.12 \mathrm{a}$ \\
\hline 9 & Cont. & $148.2 \pm 8.7 \mathrm{a}$ & $1.76 \pm 0.17 \mathrm{a}$ & $0.65 \pm 0.07 \mathrm{a}$ \\
& 7 day & $158.9 \pm 11.2 \mathrm{a}$ & $2.27 \pm 0.23 \mathrm{~b}$ & $0.76 \pm 0.09 \mathrm{a}$ \\
\hline
\end{tabular}

${ }^{1}$ S. oryzae samples at 12 months could not be processed due to extensive progeny production and fungal development on all samples, controls and treatments. Means for exposure for progeny, weight loss, and frass weight, followed by the same lowercase letter, are not significantly different ( $p \geq 0.05$, Proc $t$-test, SAS). 
Survival of parental $R$. dominica on brown rice was strongly correlated with progeny production, similar to results with this species exposed on wheat, but even when survival was $100 \%$, there was still variation in progeny production (Figure 7A). Survival of parental S. oryzae was also correlated with progeny production, with considerable survival on all treatments, very high progeny production, and variation in progeny production with $100 \%$ parental survival (Figure $7 \mathrm{~B}$ ). Progeny production of both $R$. dominica and S. oryzae in the 7 day exposures was correlated with production in the continuous exposures, with more variation in S. oryzae as reflected by the low $r$ values (Figure 8A,B). Sample weight loss and frass weight was correlated between the two parental exposure regimes for both species, with stronger correlation and greater $r$ values for R. dominica compared to S. oryzae (Figure 8C-F). Progeny production of both species was strongly correlated with sample weight loss (Figure 9A,B) and frass weight (Figure 9C,D), and frass weight was correlated with sample weight loss (Figure 9D,E), but with lower $r$ values for $R$. dominica compared to $S$. oryzae.
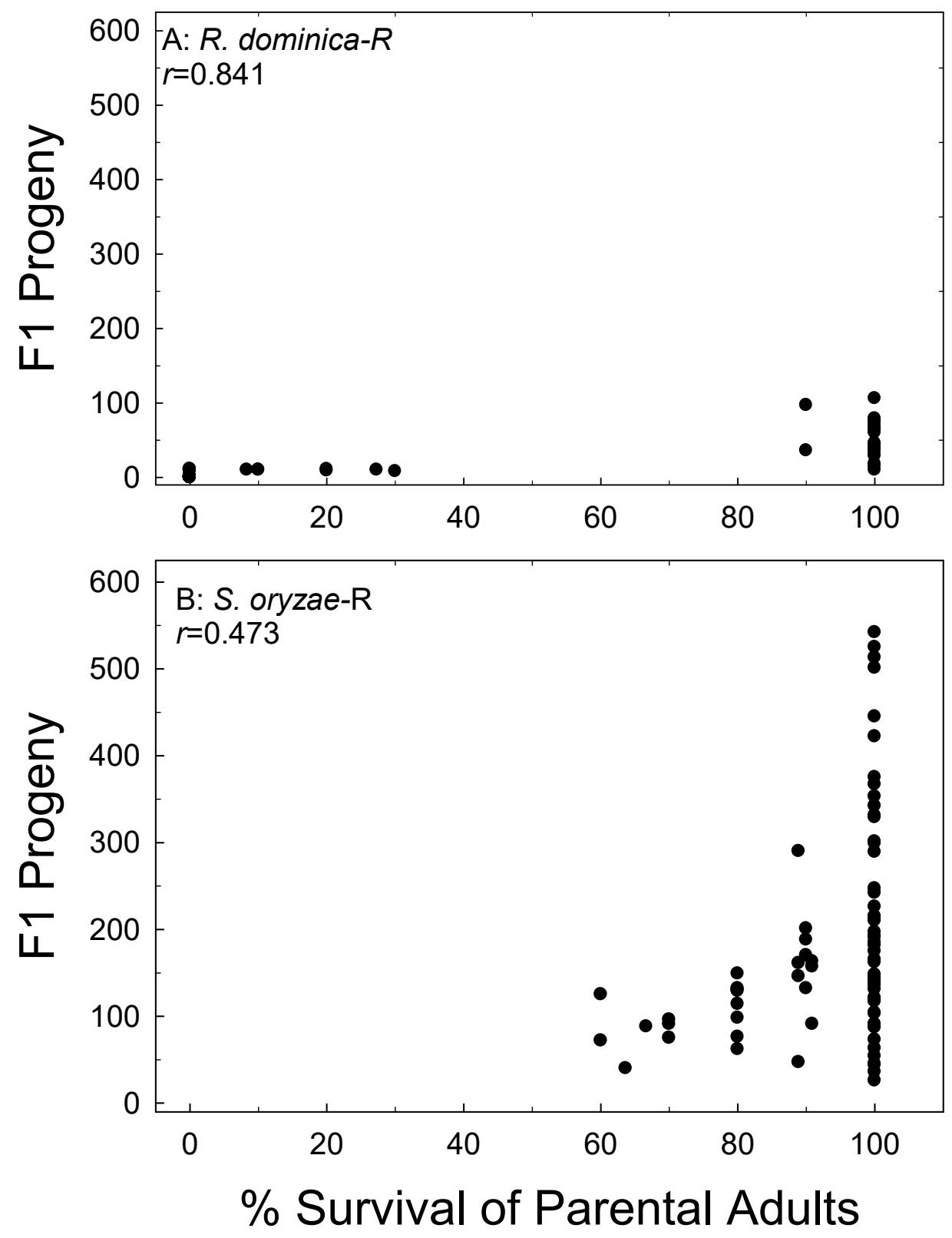

Figure 7. Correlation of parental survival with $\mathrm{F}_{1}$ progeny production of $R$. dominica (A) and S. oryzae (B) on brown rice (R). Data combined for all treatments and all bioassay months. 

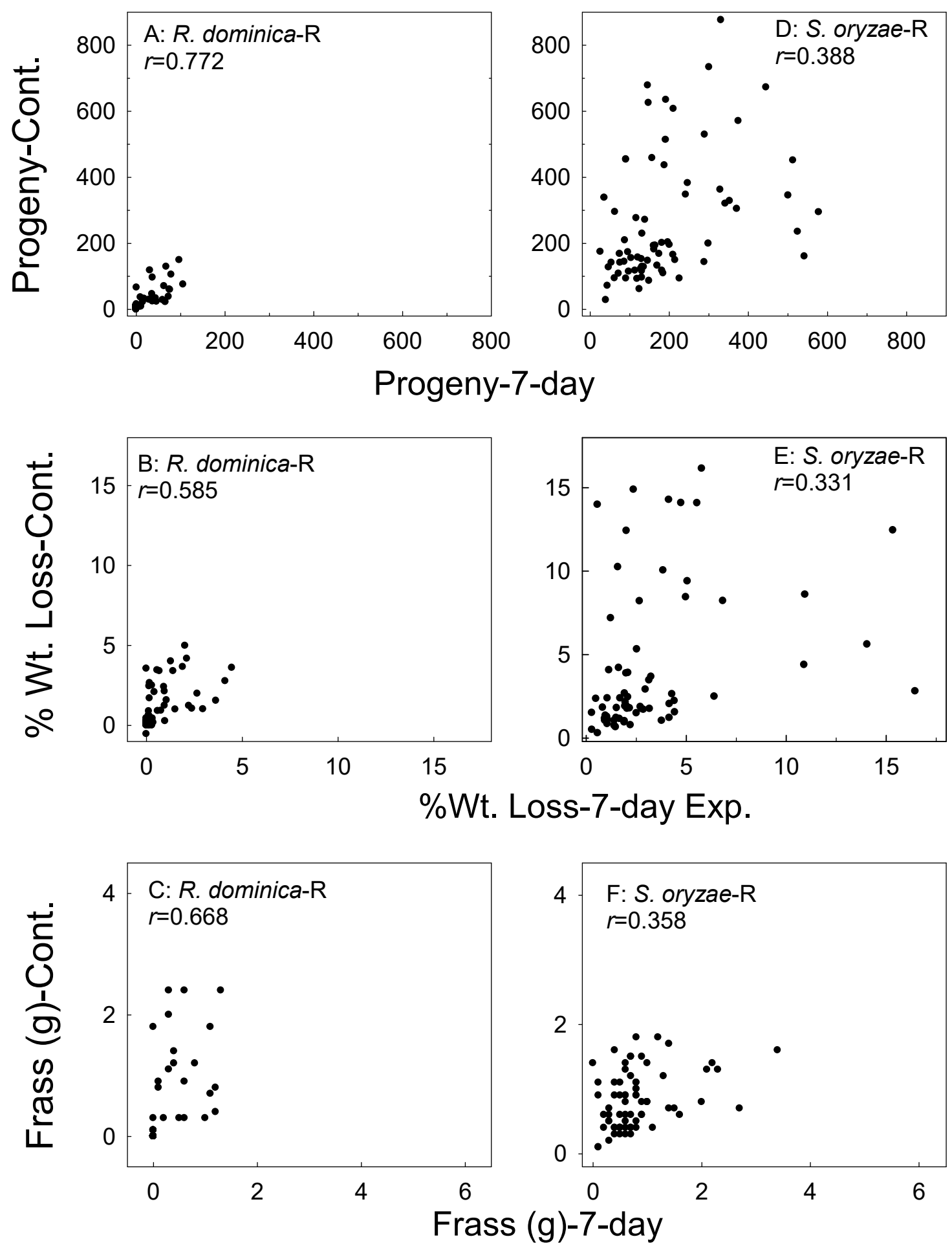

Figure 8. Correlation of $F_{1}$ progeny, sample weight loss, and feeding damage (frass weight) in the brown rice $(\mathrm{R})$ samples whereby parental adults were exposed for 7 days versus the continual exposures of parental adults for R. dominica (A-C) and S. oryzae (D-F). Data combined for all treatments and all bioassay months. 

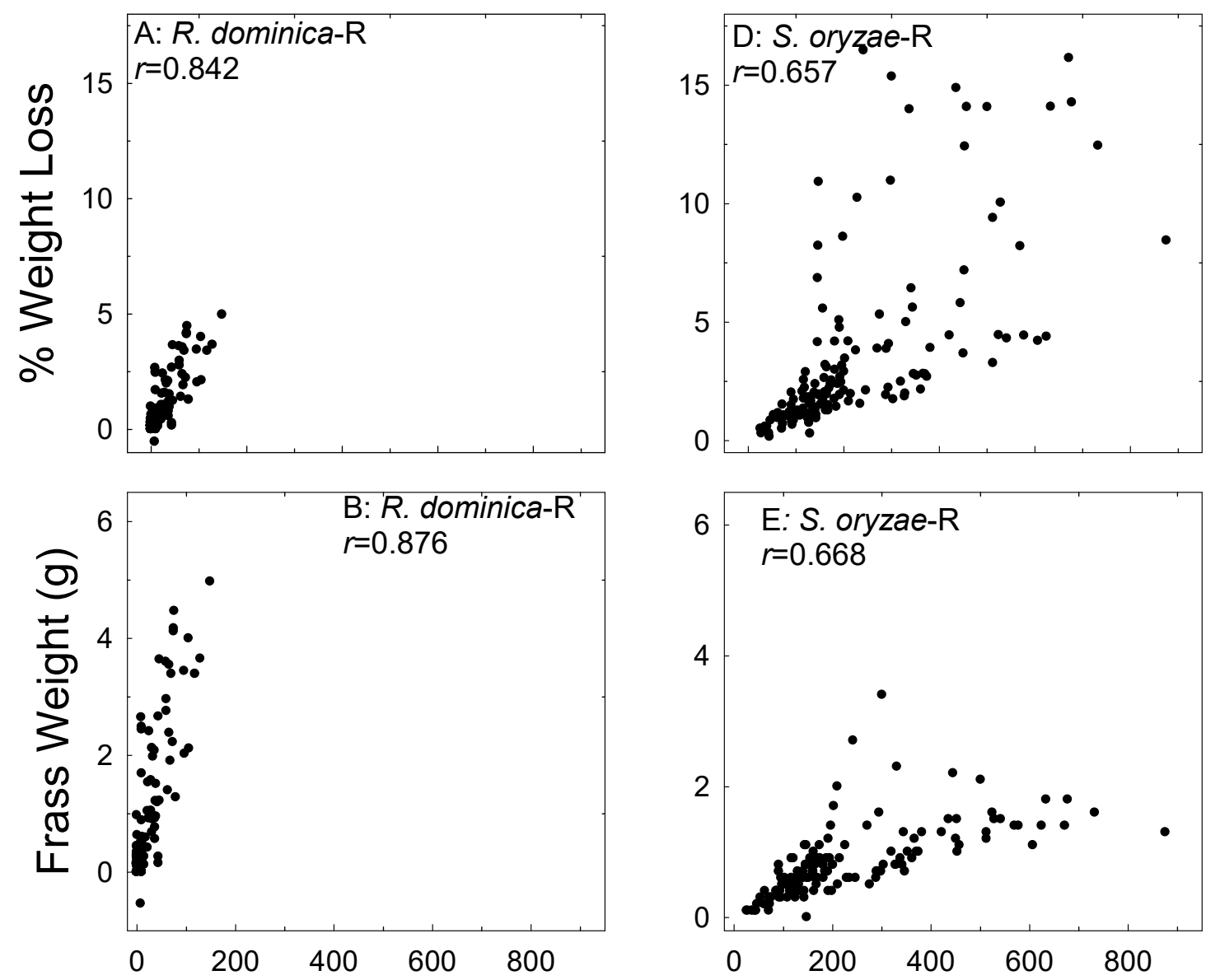

\section{F1 Progeny}

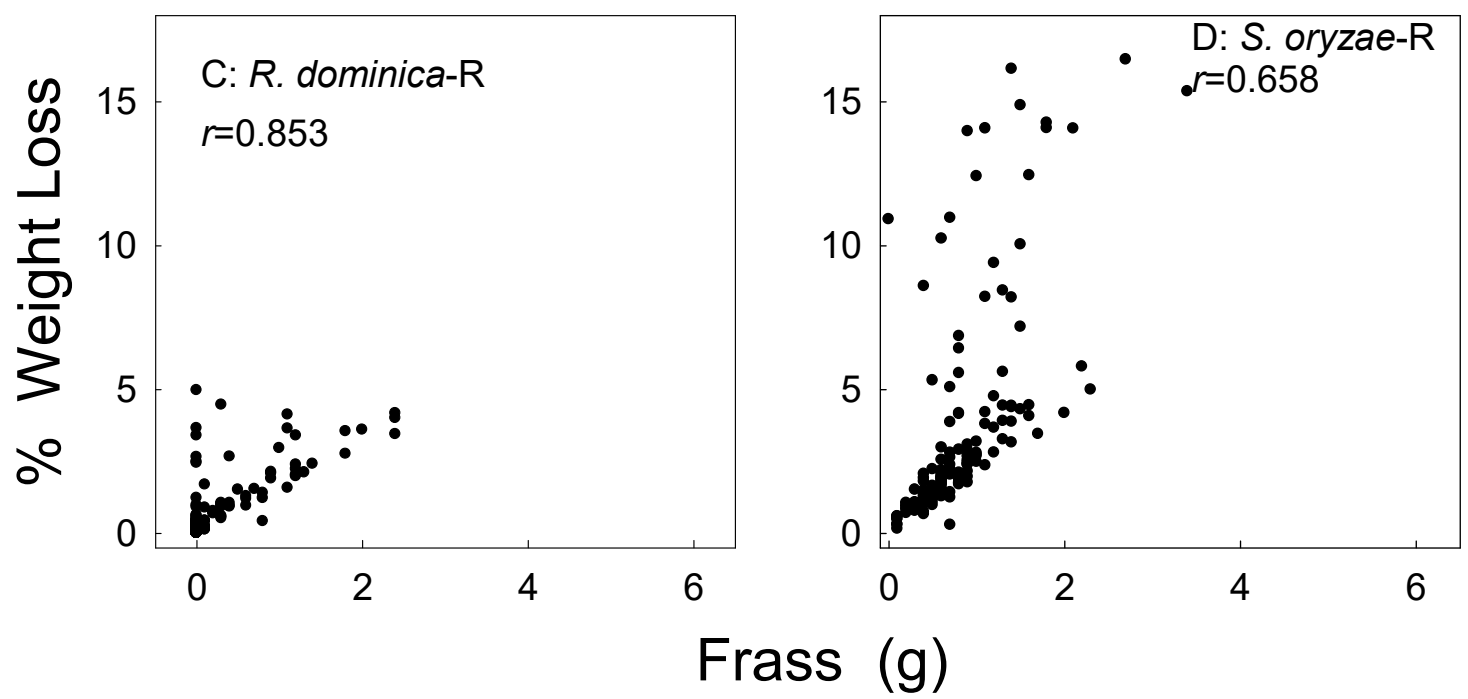

Figure 9. Correlation of brown rice $(\mathrm{R})$ sample weight loss and frass weight with $\mathrm{F}_{1}$ progeny of $R$. dominica (A,B), sample weight loss with frass weight $(\mathbf{C})$, sample weight loss and frass weight with $\mathrm{F}_{1}$ progeny of $S$. oryzae $(\mathbf{D}, \mathbf{E})$, and sample weight loss with frass weight $(\mathbf{F})$. Data for the two parental exposure regimes combined, data for all treatments and all bioassay months combined. 


\section{Discussion}

There have been several recent studies with grain protectants whereby authors have exposed parental adults, obtained mortality values, and then, held the grains to obtain progeny assessments $[16,17]$. While this is a valid methodology, one of the objectives of this study was to see if continual exposure of parental adults altered the progeny production values, using methodology that has been used for assessments of IGRs alone where parental mortality is not expected [5]. Results from this study showed that exposing parental adults for one week to assess mortality, and then waiting to do progeny counts from those exposed parental adults, did not appreciably alter the relative differences between the treatments compared to the continual exposures. In fact, the opposite occurred because in some instances, the samples were so overloaded with progeny that damage assessments could not be performed. Progeny production, sample weight loss, and insect feeding damage were all correlated with the two exposure regimes for all target species on all three commodities. Thus, it would seem that providing some measure of adult mortality after exposure should be a valid component of experimental protocols for evaluating grain protectants.

Parental mortality was clearly correlated with progeny production of all target species. While this may be expected, there is evidence from previous studies with diatomaceous earth (DE) products that while adult mortality occurred after exposure, the time interval required for death allowed for parental oviposition, and subsequent progeny production $[18,19]$. This was especially prominent for Sitophilus weevils. Historical evidence and recent research have shown that pyrethroids, including deltamethrin, can be effective on Sitophilus weevils, but either high concentrations or long exposure times at current label rates may be necessary for complete kill [20]. Physical grain damage was also correlated with progeny production, emphasizing that the purpose of an insecticidal grain protectant should be to kill adults before they are able to oviposit.

The new Gravista formulation did provide some measure of increased control of S. oryzae on wheat and S. zeamais on corn, but comparisons between the two commodities can be misleading because insecticidal efficacy can vary depending on the specific grain. Kavallieratos et al. [21] exposed adults and larvae of Trogoderma granarium (Everts), the khapra beetle, on wheat, barley, maize, and rough rice treated with six different insecticides. Mortality of larvae and adults was generally greater for all insecticides on wheat and barley compared to maize and rough rice. In a similar study [22], greater mortality of adults and larvae of Tenebrio molitor (L.), the lesser mealworm, exposed on wheat and barley treated with pirimiphos-methyl, deltamethrin, spinosad and SilicoSec compared to the same insecticides applied to maize. Plus, a corn kernel is much larger than a wheat kernel, with about 30 wheat kernels per gram compared to 3 corn kernels per gram, depending on the variety. Thus, reproduction of Sitophilus spp., an internal feeder, on corn will be much less compared to what can be produced on wheat; there may also be inherent characteristics of the two species that affect reproduction.

The husk of rough rice will offer some protection from stored product insects [23]. In the current study, none of the treatments controlled S. oryzae on brown rice, which has lost the protective husk during the milling process. Brown rice is very susceptible to $S$. oryzae, and in previous studies with brown rice, progeny of $S$. oryzae quickly depleted the food resources in untreated controls used in insecticide experiments, often creating so much mold that the brown rice was turned into a gooey mass, similar to results for the 12 month data in this study [5,24,25]. Tribolium castaneum (Herbst), the red flour beetle, can also grow and develop on brown rice [24,25]. Since brown rice is most likely to be stored in bags rather than in bulk, as it is a product sold directly to consumers, alternative treatments for brown rice, including fumigation or cold storage, may be necessary to prevent economic loss. Storing brown rice in bags that are comprised of packaging in which deltamethrin is incorporated into the laminate layers of the packaging may also be an alternative to grain protectants or used in combination with a grain protectant $[26,27]$. Field studies in Ghana have shown the utility of these bags for protecting stored bagged maize in a tropical environment [28]. A new deltamethrin-incorporated 
netting material is also effective on stored product insect adults [29] and immatures [30], and has recently been registered with the US Environmental Protection Agency.

The results of this current study also show that it is difficult to evaluate grain protectants on rough rice because of the protection provided by the husk leads to low parental survival and low progeny production of both $R$. dominica and S. oryzae [5]. In this cited study, untreated rough rice and brown rice, and rough rice and brown rice treated with methoprene alone were stored at ambient conditions for 24 months on the floor of a grain bin at the CGAHR. The rice, along with untreated wheat and corn, was bioassayed at bimonthly intervals. There was little progeny production of $R$. dominica on untreated rough rice until 18 months, which was most likely due to ageing of the rough rice and weakness developing in the husk. Both $R$. dominica and S. oryzae may require a crack or split in the rough rice husk for optimum development $[23,31,32]$. Rhyzopertha dominica can be controlled on brown rice with either methoprene or the combination methoprene-deltamethrin grain protectants $[5,6]$. However, control of S. oryzae on brown rice may require additional insecticide inputs.

\section{Conclusions}

Evaluation of insecticides can be done by exposing adults on treated grains and then removing them after a given time period, or continually exposing parental adults and examining progeny. Removing parental adults after exposure seemed to be the best method for evaluating the insecticides tested in our study. The combination treatments of the pyrethrin deltamethrin and the IGR deltamethrin, with and without piperonyl butoxide synergist, gave residual control of Rhyzopertha dominia and T. castaneum on different grains. There was some indication of increased control of $S$. zeamais on corn with the Gravista product compared to the IGR+. However, brown rice was extremely susceptible to $S$. oryzae, and none of the insecticides gave complete control of this species for the residual time period tested in this study. Brown rice is usually stored in bags inside warehouses in most developed countries, and additional insecticide treatments prior to bagging or fumigation during the time the bags are stored may be necessary to control Sitophilus spp. weevils.

Author Contributions: F.A. and W.R.M.III contributed equally to this manuscript in regards to Experimental Design, Statistical Analysis, Manuscript Construction, Final Review. Both authors also contributed equally to the final revisions after journal review. All authors have read and agreed to the published version of the manuscript.

Funding: This research received partial funding from Central Life Sciences, Inc. Schaumberg, IL, USA.

Acknowledgments: We thank Brian Barnett, Carly Rasmussen, and Mollie Toth for excellent technical assistance with sample processing and data collection. We also thank Central Life Sciences for the insecticides used in this study and for partial funding. This paper reports the results of research only. Mention of trade names or commercial products in this publication is solely for the purpose of providing specific information and does not imply recommendation or endorsement by the USDA. The USDA is an equal opportunity employer and provider.

Conflicts of Interest: The authors declare no conflicts of interest with respect to this research.

\section{References}

1. Wijayaratne, L.K.W.; Arthur, F.H.; Whyard, S. Methoprene and control of stored-product insects. J. Stored Prod. Res. 2018, 76, 161-169. [CrossRef]

2. Daglish, G.J.; Pulvirenti, C. Reduced fecundity of Rhyzopertha dominica (F.) (Coleoptera: Bostrychidae) following exposure of adults to methoprene. J. Stored Prod. Res. 1998, 34, 201-206. [CrossRef]

3. Daglish, G.J.; Wallbank, B.E. Efficacy of diflubenzuron plus methoprene against Sitophilus oryzae and Rhyzopertha dominica in stored sorghum. J. Stored Prod. Res. 2005, 41, 353-360. [CrossRef]

4. Daglish, G.J. Impact of resistance on the efficacy of binary combinations of spinosad, chlorpyrifos-methyl and s-methoprene against five stored-grain beetles. J. Stored Prod. Res. 2008, 44, 71-76. [CrossRef]

5. Arthur, F.H. Efficacy of methoprene for multi-year protection of stored wheat, brown rice, rough rice and corn. J. Stored Prod. Res. 2016, 68, 85-92. [CrossRef]

6. Arthur, F.H. Efficacy of combinations of methoprene and deltamethrin as long-term commodity protectants. Insects 2018, 10, 50. [CrossRef] 
7. Snoeck, S.; Greenhalgh, R.; Tirry, L.; Clark, R.M.; Leewen, T.V.; Dermauw, W. The effect of insecticide synergist treatment on genome-wide gene expression in a polyphagous pest. Sci. Rep. 2017, 7, 13440. [CrossRef]

8. Athanassiou, C.G.; Kavallieratos, N.G.; Tsaganou, F.C.; Vayias, B.J.; Dimizas, C.B.; Buchelos, C.T. Effect of grain type on the insecticidal efficacy of SilicoSec against Sitophilus oryzae (L.) (Coleoptera: Curculionidae). Crop Prot. 2003, 22, 1141-1147. [CrossRef]

9. Athanassiou, C.G.; Arthur, F.H.; Throne, J.E. Efficacy of grain protectants against four psocid species on maize, rice and wheat. Pest Manag. Sci. 2009, 65, 1140-1146. [CrossRef]

10. Kavallieratos, N.G.; Athanassiou, C.G.; Paschalidou, F.G.; Andris, N.S. Influence of grain type on the insecticidal efficacy of two diatomaceous earth formulations against Rhyzopertha dominica (F) (Coleoptera: Bostrychidae). Pest Manag. Sci. 2005, 61, 660-666. [CrossRef]

11. Kavallieratos, N.G.; Athanassiou, C.G.; Vayias, B.J.; Mihail, S.B.; Tomanović, Z. Insecticidal efficacy of abamectin against three stored-product insect pests: Influence of dose rate, temperature, commodity, and exposure interval. J. Econ. Entomol. 2009, 102, 1352-1359. [CrossRef] [PubMed]

12. Kavallieratos, N.G.; Athanassiou, C.G.; Korunic, Z.; Mikeli, N.H. Evaluation of three novel diatomaceous earths against three stored-grain beetle species on wheat and maize. Crop Prot. 2015, 75, 132-138. [CrossRef]

13. Vayias, B.J.; Athanassiou, C.G.; Mylonas, D.N.; Mavrotas, C. Activity of spinosad against three stored-product beetle species on four grain commodities. Crop Prot. 2009, 28, 561-565. [CrossRef]

14. Vayias, B.J.; Athanassiou, C.G.; Buchelos, C.T. Effectiveness of spinosad combined with diatomaceous earth against different European strains of Tribolium confusum du Val (Coleoptera: Tenebrionidae): Influence of commodity and temperature. J. Stored Prod. Res. 2009, 45, 165-176. [CrossRef]

15. Subramanyam, B.; Hartzer, M.; Boina, D.J. Performance of pre-commercial release formulations of spinosad against five stored-product insect species on four stored commodities. J. Pest Sci. 2012, 85, 331-339. [CrossRef] [PubMed]

16. Athanassiou, C.G.; Kavallieratos, N.G. Evaluation of spinetoram and spinosad for control of Prostephanus truncatus, Rhyzopertha dominica, Sitophilus oryzae, and Tribolium confusum on stored grains under laboratory tests. J. Pest Sci. 2014, 87, 469-483. [CrossRef]

17. Gourgouta, M.; Rumbos, C.I.; Athanassiou, C.G. Residual toxicity of a commercial cypermethrin formulation on grains against four major storage beetles. J. Stored Prod. Res. 2019, 83, 103-109. [CrossRef]

18. Arthur, F.H. Survival of Sitophilus oryzae (L.) on wheat treated with diatomaceous earth: Impact of biological and environmental parameters on product efficacy. J. Stored Prod. Res. 2002, 38, 305-313. [CrossRef]

19. Arthur, F.H.; Throne, J.E. Efficacy of diatomaceous earth to control internal infestations of rice weevil and maize weevil (Coleoptera: Curculionidae). J. Econ. Entomol. 2003, 96, 510-518. [CrossRef]

20. Kavallieratos, N.G.; Athanassiou, C.G.; Arthur, F.H. Efficacy of deltamethrin against stored-product beetles at short exposure intervals or on a partially treated rice mass. J. Econ. Entomol. 2015, 108, 1416-1421. [CrossRef]

21. Kavallieratos, N.G.; Athanassiou, C.G.; Diamantis, G.C.; Gioukaria, H.G.; Boukouval, M.C. Evaluation of six insecticides against adults and larvae of Trogoderma granarium Everts (Coleoptera: Dermestidae) on wheat, barley, maize and rough rice. J. Stored Prod. Res. 2017, 71, 81-92. [CrossRef]

22. Kavallieratos, N.G.; Michaila, E.J.; Boukouvala, M.C.; Nikaa, E.P.; Skourti, A. Efficacy of pirimiphos-methyl, deltamethrin, spinosad and silicoSec against adults and larvae of Tenebrio molitor L. on wheat, barley and maize. J. Stored Prod. Res. 2019, 83, 161-167. [CrossRef]

23. Cogburn, R.R. Domestic rice varieties: Apparent resistance to rice weevils, lesser grain borers, and Angoumois grain moths. Environ. Entomol. 1974, 3, 681-685. [CrossRef]

24. Arthur, F.H.; Hale, B.A.; Starkus, L.A.; Gerken, A.R.; Campbell, J.F.; McKay, T. Development of Tribolium castaneum (Herbst) (Coleoptera: Tenebrionidae) on rice milling components and by-products: Effects of diet and temperature. J. Stored Prod. Res. 2019, 80, 85-92. [CrossRef]

25. Arthur, F.H.; Starkus, L.A.; Gerken, A.R.; Campbell, J.F.; McKay, T. Growth and development of Tribolium castaneum (Herbst) on rice flour and brown rice as affected by time and temperature. J. Stored Prod. Res. 2019, 83, 73-77. [CrossRef]

26. Kavallieratos, N.G.; Athanassiou, C.G.; Arthur, F.H. Effectiveness of insecticide-incorporated bags to control stored-product beetles. J. Stored Prod. Res. 2017, 70, 18-24. [CrossRef]

27. Paudyal, S.; Opit, G.P.; Arthur, F.H.; Bingham, G.V.; Payton, M.E.; Gautam, S.G.; Noden, B.H. Effectiveness of the ZeroFly®storage bag fabric against stored-product insects. J. Stored Prod. Res. 2017, 73, 87-97. [CrossRef] 
28. Paudyal, S.; Opit, G.P.; Osekre, E.A.; Arthur, F.H.; Bingham, G.V.; Payton, M.E.; Danso, J.K.; Manu, N.; Nsiah, E.P. Field evaluation of the long-lasting treated storage bag, deltamethrin incorporated, (ZeroFly@Storage Bag) as a barrier to insect pest infestation. J. Stored Prod. Res. 2017, 70, 44-52. [CrossRef]

29. Morrison, W.R., III; Wilkins, R.V.; Gerken, A.R.; Scheff, D.S.; Zhu, K.Y.; Arthur, F.H.; Campbell, J.F. Mobility of adult Tribolium castaneum (Coleoptera: Tenebrionidae) and Rhyzopertha dominica (Coleoptera: Bostrichidae) after exposure to long-lasting insecticide-incorporated netting. J. Econ. Entomol. 2018, 111, 2443-2453. [CrossRef]

30. Wilkins, R.V.; Zhu, K.Y.; Campbell, J.F.; Morrison, W.R., III. Mobility and dispersal of two cosmopolitan stored product insects are adversely affected by long-lasting insecticide netting in a life stage-dependent manner. J. Econ. Entomol. 2020, in press. [CrossRef]

31. Chanbang, Y.; Arthur, F.H.; Wilde, G.E.; Throne, J.E. Hull characteristics as related to susceptibility of different varieties of rough tice to Rhyzopertha dominica (F.), the lesser grain borer (Coleoptera: Bostrichidae). J. Stored Prod. Res. 2008, 44, 205-212. [CrossRef]

32. Kavallieratos, N.G.; Athanassiou, C.G.; Arthur, F.H.; Throne, J.E. Cracked hulls affect population development of Rhyzopertha dominica in rough rice. J. Insect Sci. 2012, 12, 1-7. [CrossRef] [PubMed]

(C) 2020 by the authors. Licensee MDPI, Basel, Switzerland. This article is an open access article distributed under the terms and conditions of the Creative Commons Attribution (CC BY) license (http://creativecommons.org/licenses/by/4.0/). 